\title{
The deterioration process of limestone in the Anahita Temple of Kangavar (West Iran)
}

\author{
Vahid Barnoos, Omid Oudbashi* (i) and Atefeh Shekofteh
}

\begin{abstract}
The well-known archaeological site of Anahita Temple at Kangavar is one of the most important Iranian stone monuments. It has been dated by various authors in an interval extended from Achaemenid to Sasanian Persian Empires (sixth century BCE to seventh century AD). Significant weathering has been occurred in various stone blocks used in the construction of this monument. The aim of this research is to study the deterioration process of the stone blocks used in the Temple. It includes chemical and mineralogical analysis of stones, characterization of deterioration patterns and processes, and identification of factors influenced the process. Results have been obtained by on-site and laboratory studies, including optical microscopy, petrography, X-ray fluorescence, X-ray diffraction and scanning electron microscopy coupled with energy dispersive X-ray spectroscopy methods. They showed that low-porosity limestone and dolomitic limestone have been used in the construction of the Temple, which have a compact micritic structure with variable size calcite veins (sparite) and clay veins. According to the on-site and laboratory studies, the deterioration patterns are partially similar in majority of the stone blocks and include different types of detachments as well as biological colonisations. The multianalytical results proved that the deterioration process is mainly of physical weathering type, due to structural and chemical characteristics of the limestone as well as climate factors, temperature fluctuations in particular. It turned out that limestone characteristics (including presence of clay veins as well as heterogeneity of calcitic matrix (micrite and sparite)) can affect the behaviour of stone blocks against climate factors; helping us to find reasons behind physical weathering of limestone in the cultural/historical sites and monuments.
\end{abstract}

Keywords: The Anahita Temple, Low-porosity limestone, Deterioration, Physical weathering, Sparite, Clay veins, XRD, SEM-EDS

\section{Introduction}

Very small tools have been applied on stones of various types and other inorganic natural materials for millennia to make various objects and monuments of significant dimensions and with various functions (often combined from decorative elements and artefacts) [ 1 , 2]. This widespread using is due to different reasons, the most important of which being their availability and simple access as well as simple workability. Since the very ancient times, stone has also been used by human-beings for architectural construction due to its stability, durability and workability; though its stability and durability may

*Correspondence: o.oudbashi@aui.ac.ir

Department of Conservation of Cultural and Historical Properties, Art University of Isfahan, Isfahan, Iran decrease over time because of the weathering. Weathering is a collective set of processes that lead to alteration and cause decay in stones through physical, chemical and biological factors [3, 4]. Among them one can enumerate structural properties and mineralogical composition [5-7], as well as environmental factors including temperature and its fluctuations, moisture and water, soluble salts, atmospheric pollutants, and biological agents (such as lichens), all capable of causing decay, leading to weathering of stones [8-18].

Decay of stones in cultural heritage buildings and monuments has been the subject of various studies worldwide. These investigations considered different aspects of stone decay in several types of stones used to construct architectural and monumental heritage, including (1) types of deteriorations, decay processes, and mechanisms

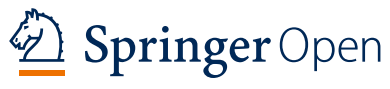

(c) The Author(s) 2020. This article is licensed under a Creative Commons Attribution 4.0 International License, which permits use, sharing. adaptation, distribution and reproduction in any medium or format, as long as you give appropriate credit to the original author(s) and the source, provide a link to the Creative Commons licence, and indicate if changes were made. The images or other third party material in this article are included in the article's Creative Commons licence, unless indicated otherwise in a credit line to the material. If material is not included in the article's Creative Commons licence and your intended use is not permitted by statutory regulation or exceeds the permitted use, you will need to obtain permission directly from the copyright holder. To view a copy of this licence, visit http://creativeco mmons.org/licenses/by/4.0/. The Creative Commons Public Domain Dedication waiver (http://creativecommons.org/publicdomain/ zero/1.0/) applies to the data made available in this article, unless otherwise stated in a credit line to the data. 
took place in different stone types [19-22], (2) factors influencing the decay and its rate [23, 24], as well as (3) application of new scientific methods for the study of decay in cultural heritage monumental stone-buildings $[25,26]$. It is worth noting that many studies merely cover a combination of the above subjects.

The so-called monumental/archaeological site of the Anahita Temple at Kangavar is the ruins of an important, large stone structure from the "Persian" period of Iranian history, spanning from the Achaemenid to
Sasanian Empires. The monument is located along the great Khorasan road and at the centre of the modern city of Kangavar, some $90 \mathrm{kms}$ east of Kermanshah in western Iran (Fig. 1a) [27, 28]. It is situated at $47^{\circ} 57^{\prime} \mathrm{E}$ (longitudinal) and $34^{\circ} 30^{\prime} \mathrm{N}$ (latitudinal) geographical coordinates. The monument is constructed over (and round) a natural hill with a maximum height of $32 \mathrm{~m}$ from the surrounding field and has a two-way staircase path (Fig. 1b-d). The Anahita Temple's plan is a square of about $209 \times 224$ meters in size. The remnants of a row of large and thick

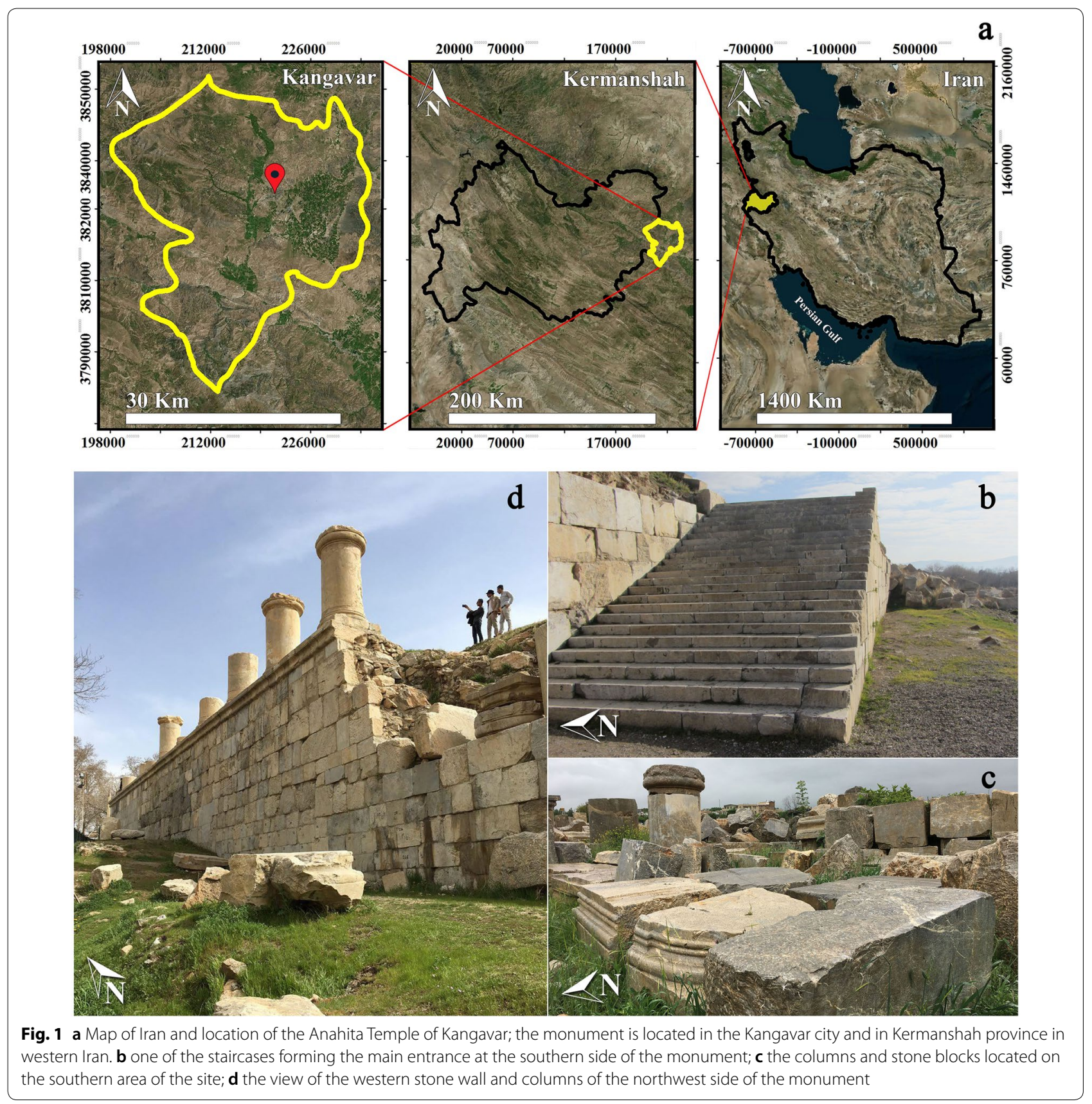


stone columns are located over the northwest side of the western wall of the Temple in their original position, including three restored ones (Fig. 1d) [28, 29].

The main construction of the archaeological complex is a massive building formed by a large square terrace $\left(46.8 \mathrm{~km}^{2}\right)$ constructed round a low, natural rock (hill). The terrace was filled with raw stone pieces and gypsum mortar to create a large, (semi-) natural/artificial hill-natural as it is shaped in rectangular form with stone pieces and gypsum mortar and then covered by large, carved stone blocks with smooth surfaces as a façade, above which two other floors were constructed. The stone blocks forming the surface of the building were joined together using iron clamps, a technique used previously by the Achaemenian stonemasters [30,31].

The Anahita Temple of Kangavar is one of the best known cultural heritage monumental sites in Iran that has attracted archaeologists/researchers interests for more than 50 years. While it has been mentioned in historical texts from about 1400 years ago, the archaeological excavations were carried out by S. Kambakhshfard (1968-1975) and continued by M. Azarnoush (19771978) just in the last century [28, 32]. Further archaeological and conservation works were performed by A. Valinoori in 1986 and from 1988 to 2001 by A. Kabiri and M. Mehryar [33]. Based on the studies performed in the site, the monument is dated back to various periods of Iranian history (Achaemenid, Parthian and Sasanian Empires, and even up to the Early Islamic era). The findings have been dated and confirmed the fact that the complex (including the Temple and surrounding area) had been in use during these four periods [30].

Historical texts as well as on-site investigations and archaeological excavations have provided various data on the architecture, history, and function of this monument [27, 28, 30,33-37]. The oldest text referred to this monument is that of Isidore of Charax (1st century $\mathrm{BCE}$ to 1st century AD). He attributed the monument to the Greek and Classical Konkobar Temple (Artemis Temple of Konkobar) in the western Iran during Parthian period [37, 38]. As Isidore firstly recognised the temple as that of Artemis, contemporary researchers considered it as a Temple of Anahita (an Iranian goddess), equivalent to Greek Artemis [29]. From the outset of archaeological excavations by S. Kambakhshfard in 1968, the monument was recognized as the Temple of Anahita (or Anahita Temple) and is dated to the Parthian period (3rd century BCE to 3rd century AD) [28]; though some published reports are dated it to the Sasanid period as well (3rd century to the 7th century AD) $[27,35]$. S. Alibaigi, contrary to S. Kambakhshfard and M. Azarnoush, asserted that the monument of Kangavar is not the Anahita Temple or an unfinished palace, but instead has probably been a palace, a residential complex, or may be a management organization from Sasanian era [27, 28, 32-35].

Foremost among environmental influences on the natural stones of Anahita Temple cultural heritage monument [39] is natural weathering due to decay. The intensity of the deterioration due to various environmental factors is clearly visible in the stone blocks. Assessing deterioration intensity and identification of decay factors are important for decision making in conservation plans of next stages of management of the site [40, 41]. For this purpose, identifying chemical compositions, microscopic observations and decay factors and patterns of the stone blocks from the Anahita Temple are necessary as part of a decay process study. Therefore, in this paper the decay process and factors affecting durability of stone blocks of the Anahita Temple of Kangavar are discussed on (on-site-) observations, laboratory and experimental studies, and finally, climatic data of the region basis. The significance of the Anahita Temple among Iranian historical monuments, the absence of an acceptable number of analytical studies on the stone monuments as well as the effect-ofdecay studies on the conservation planning and decision making, are among the main reasons behind developing a study in the Anahita Temple of Kangavar. Furthermore, the study helps researchers to develop comparative studies on the deterioration process and to identify its influencing factors on the limestone cultural heritage buildings/monuments in similar environments.

\section{Materials and methods Sampling}

In order to investigate the deterioration of stone blocks of the Anahita Temple, a research strategy was adopted by using the various scientific methods including on-site observations and laboratory analyses as well as the analysis of climatic data of the Kangavar region.

Analytical and laboratory studies were carried out on eleven stone samples (pieces) selected from different stone blocks of three sides of the monument (east, south and west) and four further stone samples from the ancient stone quarry in the Chel Maran mountain in the Temple nearby (Fig. 2). The Chel Maran stone quarry was selected in the study as recent scientific works showed that it has been used extensively for the construction of Anahita Temple, though there exist other small quarries in the region which were in use in ancient times [42]. The locations of taken samples were specified in aerial photo of the site using a eTrex 20 GPS device and was evacuated by the MapSource GPS software (Fig. 2). Detailed samples information as well as the analyses undertaken on each sample are presented in Table 1. 


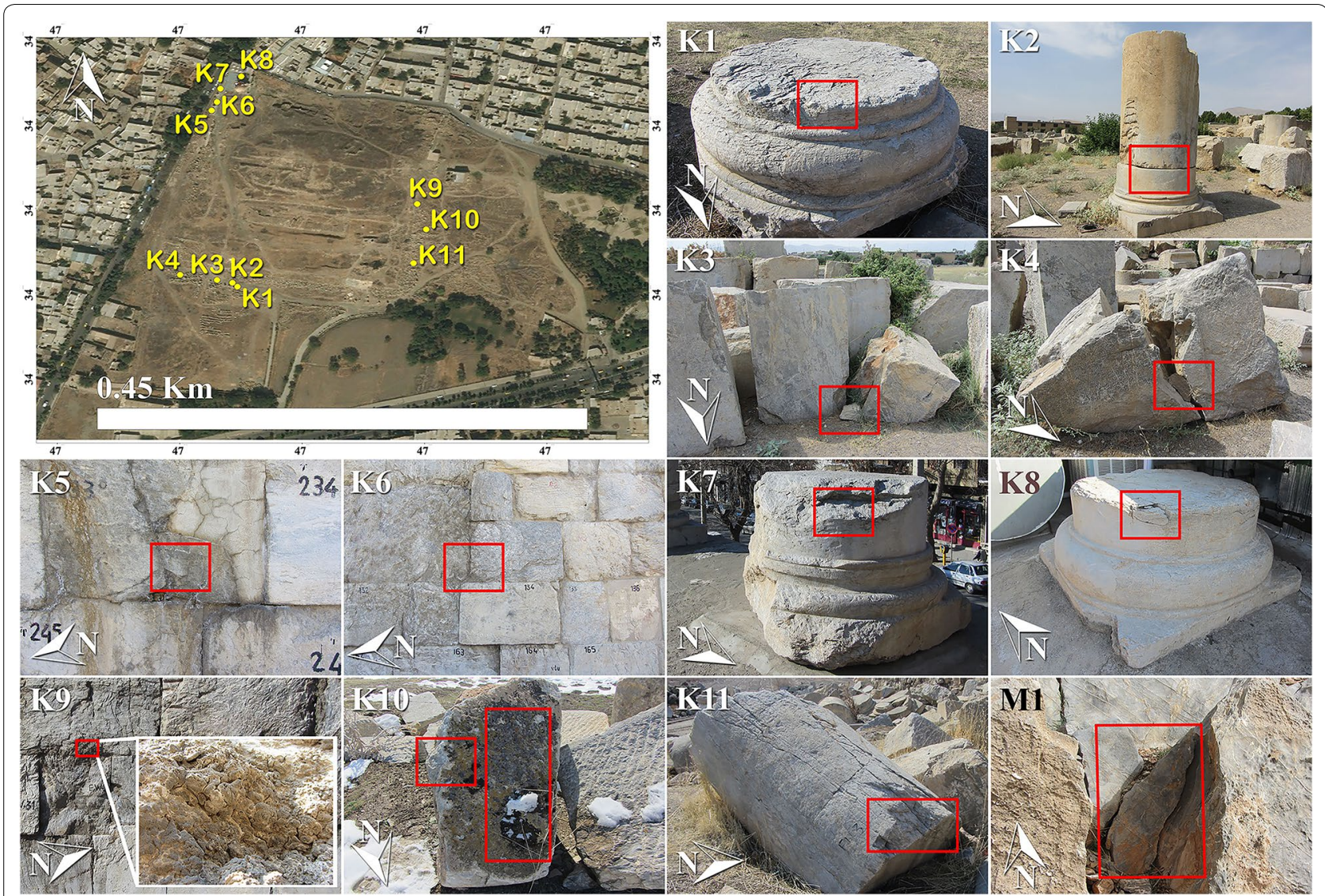

Fig. 2 The aerial view of the Anahita Temple showing areas of sampling locations, and images of the stone block of the Anahita Temple of Kangavar from which samples taken for this analysis (K Samples) and one of the samples from the Chel Maran quarry (Sample M1)

Table 1 Characteristics of the analysed samples and the type of analyses performed on each sample

\begin{tabular}{lllll}
\hline Sample & Location & Sample type & Feature & Analytical methods \\
\hline K1 & Temple (South) & Stone & Surface layer of deteriorated stone & OM, SEM-EDS \\
K2 & Temple (South) & Stone & Surface layer of deteriorated stone & OM, SEM-EDS \\
K3 & Temple (South) & Stone & Detached piece of a stone block & XRF, XRD, This section Petrography \\
K4 & Temple (South) & Stone & Detached piece of a stone block & XRF, XRD, This section Petrography \\
K5 & Temple (Northwest) & Stone & Surface layer of deteriorated stone & SEM-EDS \\
K6 & Temple (Northwest) & Stone & Surface layer of deteriorated stone & OM, SEM-EDS \\
K7 & Temple (Northwest) & Stone & Surface layer of deteriorated stone & OM \\
K8 & Temple (Northwest) & Stone & Surface layer of deteriorated stone & SEM-EDS \\
K9 & Temple (East) & Sediment & Sediment on the stone surface & XRD \\
K10 & Temple (East) & Stone, Lichen & Biological colonisation on the stone surface & OM, SEM-EDS \\
K11 & Temple (East) & Stone & Detached piece of a stone block & XRF, XRD \\
M1 & Chel Maran quarry & Stone & Intact stone core from quarry & XRD \\
M2 & Chel Maran quarry & Stone & Intact stone core from quarry & OPT \\
M3 & Chel Maran quarry & Stone & Intact stone core from quarry & OPT \\
M4 & Chel Maran quarry & Stone & Intact stone core from quarry & OPT \\
\hline
\end{tabular}




\section{Analytical methods}

The first step of the study in the site included on-site observations to characterize and classify the deterioration patterns occurred on the Temple's stone blocks. In addition to the on-site observations, microscopic observations were carried out in low magnification by optical microscopy $(\mathrm{OM})$ method in laboratory via using a stereomicroscope model ZSM-1001-3E, Iranian Optic Industries Company, on the stone pieces' surfaces (surface of taken samples). It was applied for study of decay effects in low-magnification as well as documentation of such aspects as surface features and biodeteriorations.

Petrographic studies were performed on the thin section of samples selected for the microscopic test (samples K3 and K4) by polarized light microscope BK-POL/ BK-POLR model manufactured with Alltion Company, China, equipped with Canon's EOS 400D camera. In order to detect the dolomitic phase (calcium magnesium carbonate) in thin sections, the Alizarin Red S test was performed by using a solution of Alizarin Red $\mathrm{S}$ in hydrochloric acid (10\%) on thin section of stone samples [43]. Three samples (K3, K4 and K11) were analysed by chemical and phase analysis methods (to characterize the stone types used in the Anahita Temple), including quantitative $\mathrm{X}$-ray fluorescence (XRF) and qualitative X-ray diffraction (XRD).

To study of deterioration features in stone blocks, microscopic and analytical studies were performed on the weathered samples selected from different parts of the Temple (samples K1, K2, K5, K6, K7, K8, K9, K10). The analytical studies included microscopic observations and microanalyses and were undertaken by scanning electron microscopy coupled with energy dispersive $\mathrm{X}$-ray spectroscopy (SEM-EDS).

Oriented aggregates were carried out to determine the presence of swelling clays within the structure of stones. In order to determine the clay fraction and characterization the type of the probable clay phases in the structure of the stones, one piece of stone was taken from the Chel Maran quarry (Sample M1). These tests were done on a stone sample from the Chel Maran quarry because recent analytical studies have identified it as the main resource of stone extraction for constructing the Anahita Temple; thus it shows also the present of clay minerals in the composition of stones of the Temple [42]. To dissolve calcium carbonate phase, after powdering the stone sample (M1), all of the powder was dissolved in $1 \mathrm{~N}$ solution of acetic acid $\left(\mathrm{CH}_{3} \mathrm{COOH}\right)$ in distilled water. After several cycles elapsed completing dissolution of calcium carbonate phase, the remained material was washed in distilled water. To remove probable organic materials in the sample, hydrogen peroxide $\left(\mathrm{H}_{2} \mathrm{O}_{2}\right)$ solution in $20 \mathrm{vol}$ \% was used. After washing the remained material, clay minerals were separated by centrifuging below $2 \mu \mathrm{m}$. Then the separated sample was divided into four parts: the first was isolated to be analysed later (sample code: OA). The second was exposed for $48 \mathrm{~h}$ at $60{ }^{\circ} \mathrm{C}$ to ethylene glycol for determining swelling clays (sample code: OA-EG) [44]. To identify the kaolinite phase, the third part was exposed to dimethyl sulfoxide (sample code: OA-DMSO) at $80^{\circ} \mathrm{C}$ for $72 \mathrm{~h}$. And finally, to determine the presence of chlorite phase, the last part was heated up to $550^{\circ} \mathrm{C}$ for 90 min (Sample code: OA-550) [45, 46]. Then, all treated samples were analysed by XRD method.

For open porosity measurement, a hydric test (HT) was performed. Three samples were also selected from the Chel Maran quarry (Samples M2, M3 and M4). The test was undertaken according to UNE-EN 1936 standard to determine the open porosity $\left(\mathrm{P}_{\mathrm{HT}}\right)$ [47]. In open porosity measurements with the aid of the equation:

$$
\mathrm{P}_{\mathrm{HT}}=\frac{\mathrm{M}_{\mathrm{S}}-\mathrm{M} 0}{\mathrm{M}_{\mathrm{S}}-\mathrm{M}_{\mathrm{H}}} \times 100
$$

$\left(\mathrm{P}_{\mathrm{HT}}\right)$ is open porosity based on hydric test, $\left(\mathrm{M}_{0}\right)$ is the mass of the dried specimen, $\left(\mathrm{M}_{\mathrm{S}}\right)$ is the mass of the specimen saturated with water under the vacuum, and $\left(M_{H}\right)$ is the mass of the specimen saturated with water under the vacuum and weighted in water.

The surface of some stone blocks in the Anahita Temple, especially on its eastern side, is covered with a thick crust that may be a deterioration product. To identify this crust, a sample was selected from the eastern side (sample K9) and was analysed by XRD method to identify the chemical composition of the crust.

XRD analysis on different samples (stone, surface crust and separated clay) were performed by an X-ray diffractometer D8 ADVANCE model, manufactured by Bruker AXS (Germany) and with a CuKa source with wavelength of $1.54 \AA$. The chemical composition of the stone samples was measured using a XRF analyser, S4 PIONEER model, Bruker AXS (Germany) with Rh lamp. Microstructural observations were carried out in high magnification with scanning electron microscopy (SEM) method by using a TESCAN MIRA3 model SEM microscope equipped with an energy dispersive X-ray spectrometer (EDS). SEM micrographs were taken in both backscattered electron (BSE) and secondary electron (SE) modes, and all the samples were prepared by gold coating before inserting in the machine.

Finally, the climatological information of the Kangavar area were provided using climatic data obtained from the Kangavar climatology station at the period of 1987 to 2014, derived from the database of Iran Meteorological Organization [48]. 


\section{Results and discussion}

\section{Characterization of stone}

Petrographic studies on the thin section of two samples (K3 and K4) showed a presence of calcite $\left(\mathrm{CaCO}_{3}\right)$ as the matrix of stone samples (Fig. $3 \mathrm{a}-\mathrm{c}$ ). All samples have sedimentary features with two different calcite textures (Fig. 3b), including a fine-grained matrix and coarsegrained veins. The size of calcite crystals in the matrix and veins are not equal, although it is almost the same in the veins. The coarse-grained calcite veins include secondary calcite crystals that are different in size with the fine-grained calcite matrix, probably due to the different conditions of crystallization. On the other hand, some fine and narrow veins are visible in the microstructure of the samples, being compositinally different from the calcitic texture. These are consisting of very fine veins filled with non-carbonate (probably silicate) phases especially of clay minerals. In fact, perhaps differences in the matrix and veins (secondary calcite and clay) due to the diagenesis conditions of sedimentary stone. Based on the petrographic observations, stones consist of finegrained texture (micritic calcite) and coarse-grained secondary calcite veins (sparite). The majority of the texture of samples is composed of micritic crystals that has more impurity than the sparite veins. In fact, these impurities include clay or iron compounds within composition of the primary calcite (micritic matrix), compared with secondary coarse-grained calcite. Evidence of some small-size quartz $\left(\mathrm{SiO}_{2}\right)$ crystals is also observed within stone texture, to be confirmed with the XRD analysis reported in the following pages. The previously petrographic (and analytical) study on the stone quarries used in construction of the Anahita Temple, as well as on stones used in this monument is well matched with the petrographic observations in present study [42].

Furthermore, several micro-cracks are evident in the microstructure of stones, which can be observed particularly in the thin section of sample K4 (Fig. 3b). Also the cleavage is clearly visible in the texture of the sparite veins of this sample (Fig. 3b). As noted above, narrow veins are present in the stone microstructure probably filled with fine-grained clay minerals that are not formed in the coarse-grained sparite veins. In some areas, some holes are formed in the clay veins that probably contain
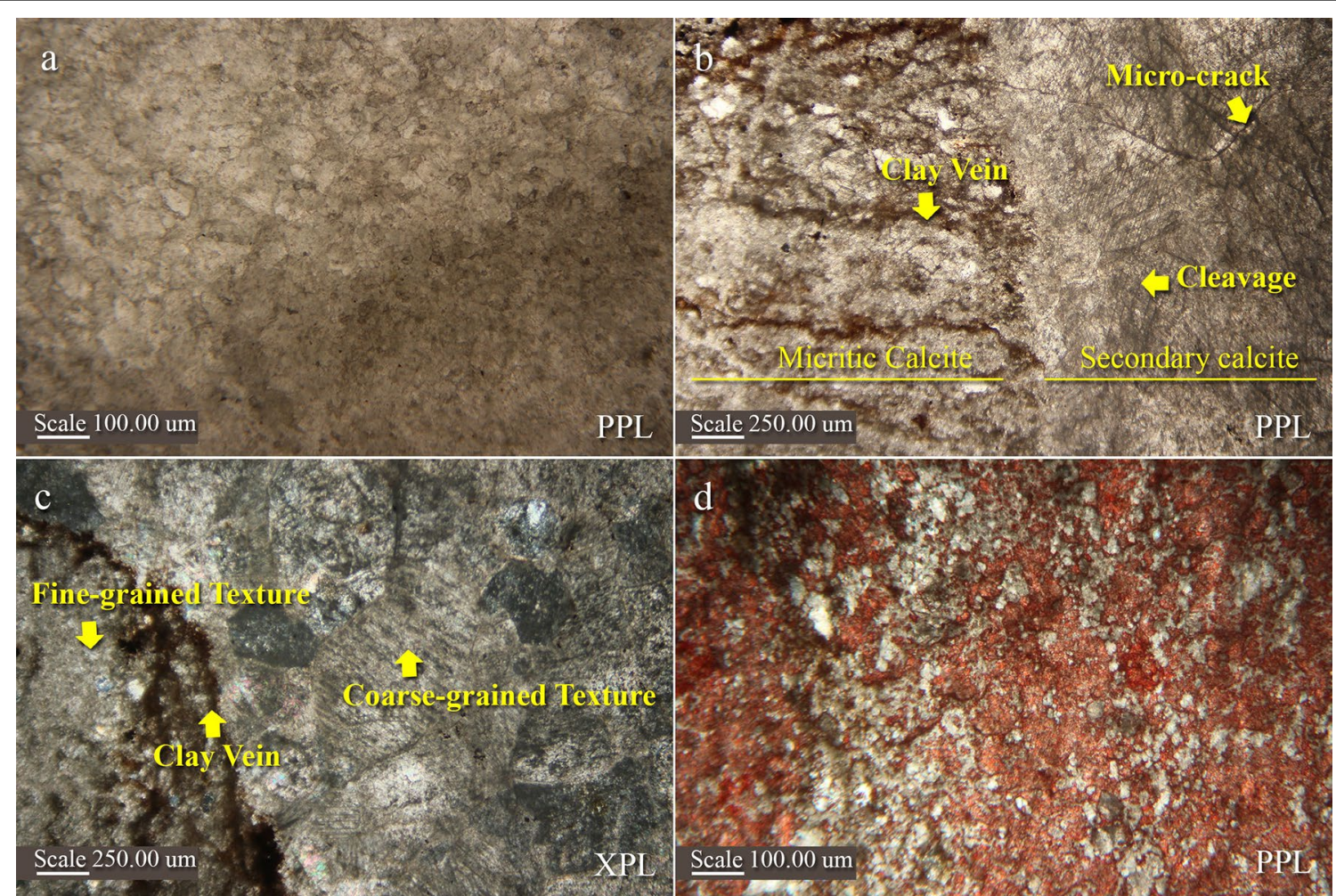

Fig. 3 Thin section petrography micrographs of stones samples from the Anahita Temple. a The micrograph of the sample K3, showing the matrix of micrite with a compact texture and low porosity; $\mathbf{b}$ the micrograph of the sample K4, which shows secondary calcite formed within the compact calcite matrix, clay veins, and the presence of cleavage and micro-crack in the stone structure; $\mathbf{c}$ the micrograph of the sample K3 in dark field (XPL); the image shows multi-texture structure of stone in form of "fine-grained texture (micritic)" and "coarse-grained texture (sparite)" and placement of clay veins between two textures; $\mathbf{d}$ the micrograph of the sample K4 indicating the dolomite phase in the stone texture using Alizarin Red S test 
iron compounds. The clay veins are located in the boundary of two main calcitic textures of the stone: micritic matrix and secondary sparite. Figure 3c shows secondary sparite with large and coarse grains beside micritic texture, and clay veins of dark color are located at the boundary of these textures. The Alizarin Red S test was perofrmed on the thin section of sample $\mathrm{K} 4$ and revealed a presence of fine-grained dolomite $\left(\mathrm{CaMg}\left(\mathrm{CO}_{3}\right)_{2}\right)$ phase within calcite crystals in this sample. Therefore the presence of dolomite mineral proved in the texture of the Anahita Temple's stones in previously published works, is proved once more with this test [42].

The results of the XRF analysis of three stone samples from the Temple (samples K3, K4 and K11) showed that $\mathrm{CaO}$ is the major constituent of composition (Table 2). $\mathrm{CaO}$ is measured varying from 32 and 50 wt \% and the amount of $\mathrm{SiO}_{2}$ varies from $2.83 \mathrm{wt} \%$ to $11.60 \mathrm{wt} \%$. $\mathrm{MgO}$ varies also between 2.53 and 17.66 wt \%. Given the abundance of $\mathrm{CaO}$, representing limestone, the presence of magnesium can also be interpreted as an evidence of a dolomite presence in the stone composition, as is also revealed in petrographic observations $[49,50]$. According to the presence of calcite in petrographic study and of a $\mathrm{CaO}$-rich stone in the chemical analysis, it can be said that stones used in the Temple were calcareous (carbonate) ones. There are different methods for characterizing types of calcareous (carbonate) stones based on their chemical as well as phase compsotion [42]. According to the ratio of $\mathrm{MgO}$ to $\mathrm{CaO}$ $(\mathrm{CaO} / \mathrm{MgO})$, sample $\mathrm{K} 3$ is limestone, while samples $\mathrm{K} 4$ and $\mathrm{K} 11$ are dolomitic limestone [51]. The result of previous study on the stones of Anahita Temple and ancient stone quarries in its nearby region have showed that the stones used in the site were more limestone, while stones in different quarries have been detected to be from limestone to dolomitic limestone [42]. It is worth noting that based on the method used to identify the type of carbonate stones, the stones used in the Anahita Temple can be classified as limestone or dolomitic limestone. On the other hand, the concentration of $\mathrm{MgO}$ in the compsoiton of analysed stones is significantly higher than the samples that are analysed in previous work. Thus, the result of analysis of the samples in currect study well matches with the provious data obtained from analysis of stones quarries and shows that other quarries (in addition with Chel Maran) may have been used in construction of the Anahita Temple. Other identified constituents are $\mathrm{Al}_{2} \mathrm{O}_{3}, \mathrm{Fe}_{2} \mathrm{O}_{3}$ and $\mathrm{K}_{2} \mathrm{O}$, which are measured in considerable amounts in sample K11. In fact, significant concentartion of aluminum, magnesium, silica, iron and potassium oxides in the XRF results might be indicative of the presence of quartz and clay minerals (silicates) in the sample [52, 53].

The results of XRD on three samples (samples K3, K4 and $\mathrm{K} 11)$ indicated the presence of calcite $\left(\mathrm{CaCO}_{3}\right)$ as the major phase in the composition of the stones. Dolomite $\left(\mathrm{CaMg}\left(\mathrm{CO}_{3}\right)_{2}\right)$ and quartz $\left(\mathrm{SiO}_{2}\right)$ have also been identified beside the calcite in all analysed samples (Fig. $4 \mathrm{a}-\mathrm{C}$ ). Quartz is found as minor phase in the composition of many sedimentary and carbonate stones [54]. The presence of a significant amount of $\mathrm{MgO}$ in the XRF analysis of these sample confirms the presence of dolomite in the XRD results, particularly in sample $\mathrm{K} 4$ where $\mathrm{MgO}$ is measured about $17.5 \mathrm{wt} \%$ and dolomite is determined as the major phase in its XRD analysis (Fig. 4b). Other minor phases identified in sample $\mathrm{K} 11$ are illite $\left(\left(\mathrm{K}, \mathrm{H}_{3} \mathrm{O}\right)\right.$ $\left.\mathrm{Al}_{2} \mathrm{Si}_{3} \mathrm{AlO}_{10}(\mathrm{OH})\right)$ as well as albite $\left(\mathrm{NaAlSi}_{3} \mathrm{O}_{8}\right)$ (Fig. 4c). Illite is known as a clay mineral whereas albite is a feldspar plagioclase $[55,56]$. It is worth noting that the phase composition of sample K11 is similar to that of two other samples from the core of stone pieces; while presence of illite and albite may be due to presence of these phases in the stone structure.

The XRD results of clay fraction (oriented aggregates) from sample M1 are presented in Fig. 5. The results of treated samples indicate muscovite $\left(\mathrm{KAl}_{2} \mathrm{Si}_{3} \mathrm{AlO}_{10}(\mathrm{OH})_{2}\right)$ and illite as the main phases. Illite is a mica-like clay mineral, a low-temperature phase with triangular structure and almost similar to the structure and composition of muscovite. Muscovite is a clay mineral in the group of micas [56, 57]. Mica group is known as low-swelling silicate minerals $[58,59]$. The clay and silicate minerals are including illite, muscovite and albite (as identifed in analysis of stone samples of Temple) and are more probably related to secondary dark veins observed in the microstructure of the stones (Fig. 3, thin section petrography).

Table 2 Quantitative results of XRF analysis of three stone samples (wt \%)

\begin{tabular}{|c|c|c|c|c|c|c|c|c|c|c|c|c|c|c|c|c|c|}
\hline Sample & $\mathrm{CaO}$ & $\mathrm{SiO}_{2}$ & $\mathrm{MgO}$ & $\mathrm{Al}_{2} \mathrm{O}_{3}$ & $\mathrm{Fe}_{2} \mathrm{O}_{3}$ & $\mathrm{CuO}$ & $\mathrm{K}_{2} \mathrm{O}$ & $\mathrm{ZnO}$ & $\mathrm{SO}_{3}$ & SrO & $\mathrm{TiO}_{2}$ & $\mathrm{MnO}$ & $\mathrm{PbO}$ & $\mathrm{Cl}$ & $\mathrm{Na}_{2} \mathrm{O}$ & $\mathrm{Rb}_{2} \mathrm{O}$ & $\mathrm{LOI}^{\mathrm{a}}$ \\
\hline K3 & 49.74 & 8.13 & 2.53 & 0.42 & 0.40 & 0.22 & 0.09 & 0.08 & 0.04 & 0.03 & 0.03 & 0.02 & - & - & - & - & 38.18 \\
\hline KM & 31.97 & 2.83 & 17.66 & 0.30 & 2.03 & 0.31 & 0.06 & 0.13 & 0.02 & 0.01 & - & 0.11 & 0.02 & 0.02 & - & - & 44.37 \\
\hline K11 & 38.54 & 11.60 & 5.81 & 4.71 & 2.24 & 0.09 & 1.16 & 0.03 & 0.06 & 0.02 & 0.24 & 0.03 & - & - & 0.20 & 0.60 & 35.12 \\
\hline
\end{tabular}

a Loss on ignition $\left(1000^{\circ} \mathrm{C}, 2 \mathrm{~h}\right)$ 
$\mathbf{a}^{1400}$
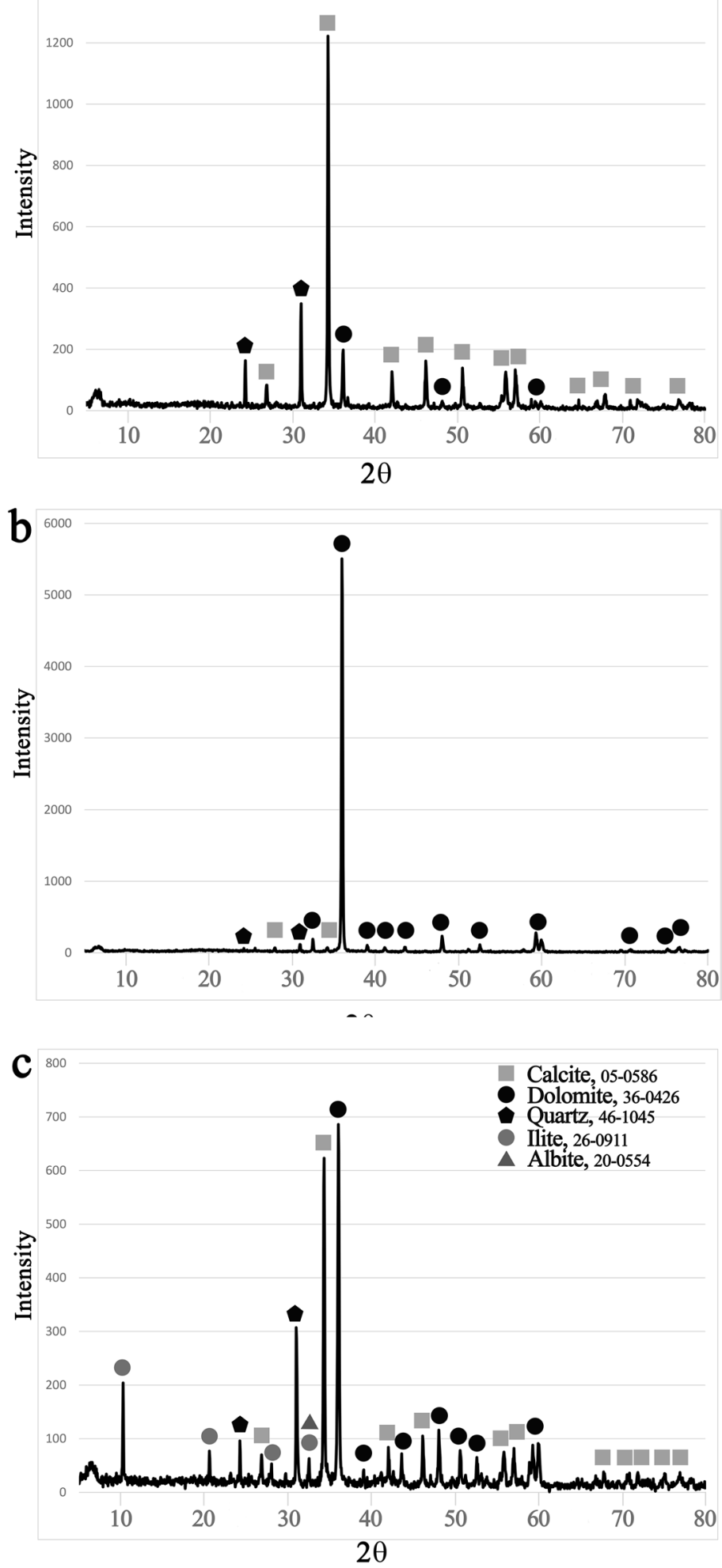

Fig. 4 The XRD patterns (X-ray diffractograms) of the stone samples indicating phase composition of stones used in the Anahita Temple. a X-ray diffractogram of sample K3 represents the calcite, quartz and dolomite; $\mathbf{b}$ X-ray diffractogram of sample K4, the XRD analysis represents dolomite, calcite and quartz in the stone; $\mathbf{C X R D}$ result of sample K11, indicating calcite, dolomite, quartz, illite and albite 
Table 3 Data from open porosity measurement of three stone samples from the Chel Maran stone quarry [47]

\begin{tabular}{lllll}
\hline Sample & $\begin{array}{l}\mathbf{M}_{\mathbf{0}} \\
\text { Gram }\end{array}$ & $\mathbf{M}_{\mathbf{S}}$ & $\mathbf{M}_{\mathbf{H}}$ & $\begin{array}{l}\mathbf{P}_{\mathbf{H T}} \\
\text { Percent }\end{array}$ \\
\hline M2 & 173.94 & 174.27 & 109.85 & 0.51 \\
M3 & 179.52 & 179.82 & 113.36 & 0.45 \\
M4 & 180.13 & 180.35 & 113.64 & 0.33 \\
\hline
\end{tabular}

$M_{0}$ the mass of the dried specimen, $M_{S}$ the mass of the specimen saturated with water under vacuum, $M_{H}$ the mass of the specimen saturated with water under vacuum and weighted in water, $P_{H T}$ open porosity in percent

The the data and result of open porosity measurement on the three stone samples from the Chel Maran quarry, based on the method mentioned earlier, are presented in Table 3 . The porosity in the samples is measured between 0.33 to 0.51 percent with the average of 0.43 percent. It reveals that the porosity is very low in the structure of the stones of the Anahita Temple; and thus we can categorize it as a low-porosity limestone.

According to the results of analyses, the stones used in the construction of the Anahita Temple of Kangavar have been limestone and dolomitic limestone [49-51], as was previously observed as well [42]. The structure of the stones is sedimentary compact, low-porosity and layered, with some secondary vein within the texture. The vein texture is visible in two forms in the microstructure of the stones:

1. Bright veins of secondary sparite calcite within micitic matrix of stone;

2. Unstable veins of clay and silicate minerals, such as illite, muscovite and albite.

The microstructure of the stones mainly includes sparite in the form of secondary calcite veins, along with the fine-grained calcite (micrite) texture of the stones. According to petrographic observations, secondary calcite has less impurity than the matrix in terms of crystallography, as the porosity in the compact micritic crystalls of matrix is low in appearence. Besides secondary calcite, clay minerals are filled the narrow veins of the stones of the Anahita Temple. Hence the main charactersitics of the Anahita Temple stones are the presence of microcracks in texture, as well as the secondary calcite and the clay veins that may lead to heterogeneity of the stone structure; the latter may cause a long-term weakness of stone while exposed before an outdoor environ.

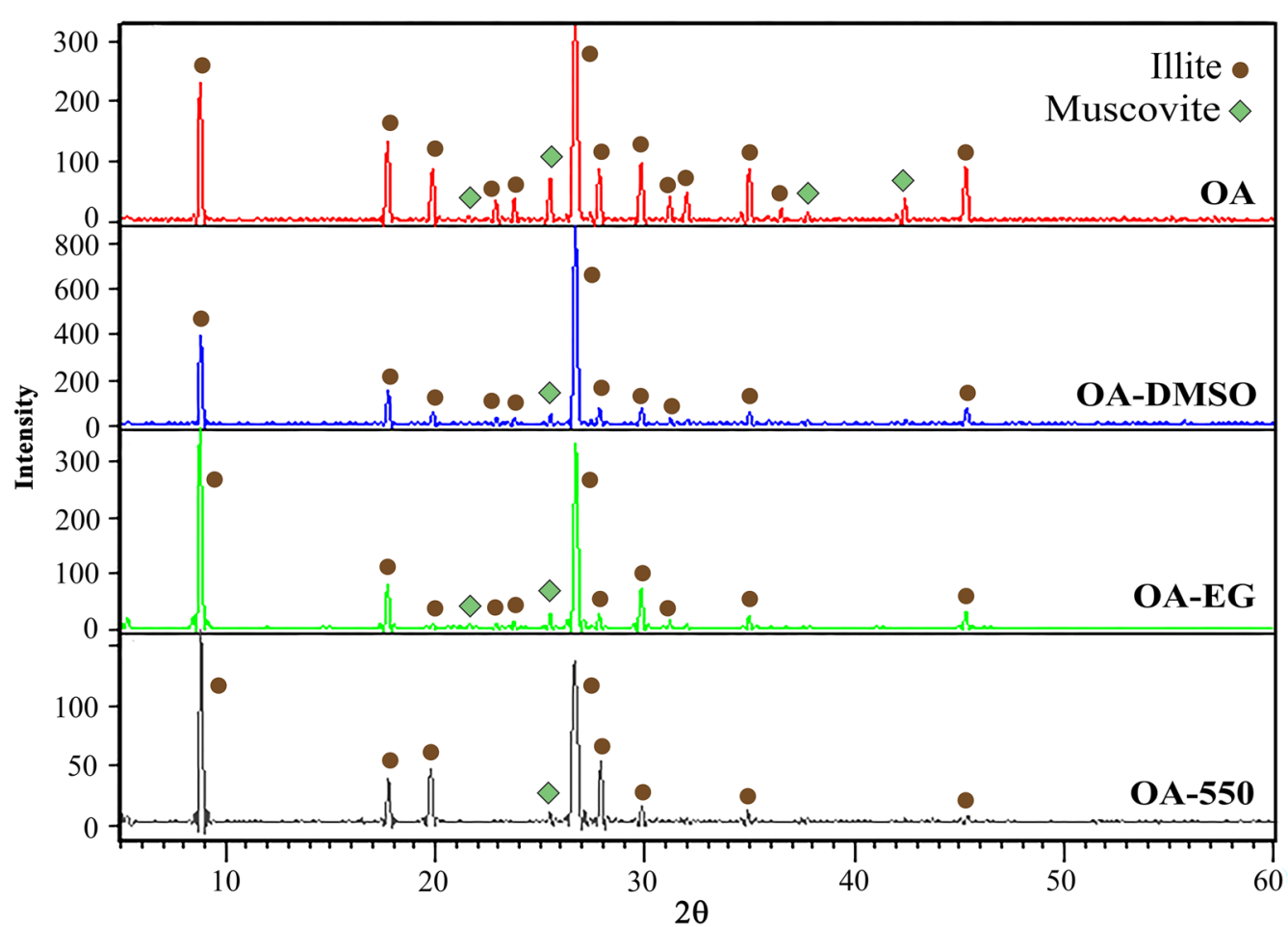

Fig. 5 The comparative X-ray diffractograms of the separation of clay minerals; the sample is from the Chel Maran quarry (sample M1); the results show illite and muscovite as the major phases in different types of sample 
Table 4 Results of the EDS analysis of stone samples including the stone section and degraded surface of stone

\begin{tabular}{|c|c|c|c|c|c|c|c|c|c|c|c|c|c|}
\hline Sample & Analysis & 0 & $\mathrm{Ca}$ & $\mathrm{Si}$ & $\mathrm{Mg}$ & Al & $\mathrm{Fe}$ & $\mathrm{K}$ & $\mathrm{Na}$ & $S$ & $\mathrm{Cl}$ & $P$ & $\mathrm{Zn}$ \\
\hline K2 & A & 49.42 & 36.49 & 1.37 & 1.67 & 1.28 & 0.06 & 0.33 & 1.56 & 4.12 & 0.71 & - & - \\
\hline \multirow[t]{2}{*}{ K1 } & B & 52.69 & 5.76 & 20.39 & 5.19 & 10.35 & 1.85 & - & - & 3.77 & - & - & - \\
\hline & $C$ & 49.05 & 16.69 & 21.88 & 4.28 & - & 1.41 & 1.46 & 1.49 & 3.13 & 0.61 & - & - \\
\hline \multirow[t]{2}{*}{ K6 } & $\mathrm{D}$ & 40.51 & 33.50 & 4.08 & 3.65 & 5.06 & 0.27 & 1.27 & 2.65 & - & 1.05 & 2.29 & - \\
\hline & $E$ & 38.56 & 22.32 & 14.06 & 3.17 & 11.21 & 0.06 & 2.80 & 2.63 & - & 0.98 & 1.81 & - \\
\hline \multirow[t]{3}{*}{ K10 } & $\mathrm{F}$ & 44.56 & 36.89 & 3.75 & 2 & 2.80 & 0.21 & 1.01 & 2.78 & - & 1.52 & 1.74 & - \\
\hline & G & 29.95 & 57.23 & 0.92 & 0.27 & 0.21 & 0.10 & 0.42 & - & - & 0.41 & 0.53 & 0.09 \\
\hline & $\mathrm{H}$ & 26.38 & 72.80 & - & - & - & 0.42 & - & - & - & - & - & 0.40 \\
\hline
\end{tabular}

Matrix of sample K2 (analysis A) represents the calcite-based texture along with other minerals such as probable clay with sulphur and phosphorus. EDS analysis of a phase in stone matrix in sample K1 (analysis B) shows evidence of clay minerals with less content of calcium and sulphur. In matrix of sample K1 (analysis C), calcium and the elements of clay minerals are detected. Analysis of the phase observed in sample K6 (analysis D) as well as matrix analyses of samples K6 and K10 (Analyses $\mathrm{E}$ and $\mathrm{F}$ respectively) show the calcite texture of the stone with silica, magnesium, iron, aluminium, potassium and sodium, as well as evidences of sulphur, phosphorus and chlorine. Analysis $\mathrm{G}$ in sample $\mathrm{K} 10$ represents calcite phase with about $10 \%$ sulphur. Other elements, such as silicon, are measured less than $1 \%$ in this analysis. Also analysis $\mathrm{H}$ in sample K10 represents a calcite-rich phase in the structure. The SE and BSE micrographs are presented in Fig. 9

\section{Deterioration studies}

Study of deterioration patterns and typology of the decays over time is an important and interesting subject in the issue of cultural heritage stone monuments. This kind of on-site study can comfort to characterize the type of decays according to appearenec and morphology of the remnant of the decay; including surface of the studied stone blocks and objects. Consequently, it is possibe to classify the deterioartions detected in one site or monument, and then study and analyse the issue in some detail and with more sophisticated methods and tools [60-62]. Based on the glossary provided by ICOMOS-ISCS on stone deterioration patterns [60], the major deterioration patterns detected in the stone blocks of the Anahita Temple of Kangavar are categorized in the "detachment" group.

The on-site observations show that highest frequency of this type of deterioration pattern covers "delamination", "scaling" and "fragmentation" forms (Figs. 6a-f) [60]. One of the important reasons for happenning of delamination in stones could be cracks at the original used stone [61], as this pattern occurred in the stones of the Temple. In many areas, scaling has caused the separating pieces of small and large scales in the forms of spalling (or contour scaling) and flaking [60, 62]. These detachment's type deteriorations have been occurred along the sedimentation layers and veins. "Bursting" is another type of deterioration pattern that occurred in some stone blocks in the Temple (Fig. $6 \mathrm{~g}, \mathrm{~h}$ ). This decay type might be caused by geological factors such as an earthquake, as it is apparent in the column shown in Fig. 6g. In the literature, the high risk possibility of the earthquake in the Kangavar region is mentioned and in fact the happening of an earthquake has been recorded in the past [28, 63]. As there is still some ambiguity on the subject, another reason could be the displacement of the stone blocks and their falling off from the platform. In some stone blocks used in the south wall of the monument, another type of bursting is visible in the edges of blocks, which may be occurred due to stress exerted from the heavy stone blocks (Fig. 6h). The other type of deterioration patterns is "alveolization" on the surface of stone blocks, which is observed in some blocks of the eastern and western walls of the Temple and was probably produced by some contaminations (depositions) on the surface of few stones (Fig. 6i). These depositions often form by introduction of soluble or insoluble substrates from the materials surrounded the stone blocks such as mortar, resulting the formation of hard crust on the surface of stones. The main reason for this movement may be either rainfall or water-moisture raised from the ground. In some blocks, a phenomenon similar to "rillenkarren" is occurred in the form of fissures parallel to the curved and perpendicular edges at the surface, as seen in Fig. 6j. Rillenkarren are patterns of tightly packed, small solution rills or channels with about 20-30 $\mathrm{mm}$ found upon bare and separated by sharp angular ridges, sloping surfaces of soluble rocks in all climates $[64,65]$.

Biological colonisation (including lichens) is another phenomenon observed as a significant deterioration pattern in some areas of Anahita Temple of Kangavar (Figs. 6k and 7e, f). Though the intensity and development is partially low on the surface of stone blocks, it is a little more considerable in the eastern and south-eastern sides of the monument that shows more biological activities of lichens in this area of the monument, probably due to lower average stone surface annual temperature in the area [66]. In some columns and in many of the stone blocks used in walls of the monument's platform, cement mortar is used for joining and filling large cracks 


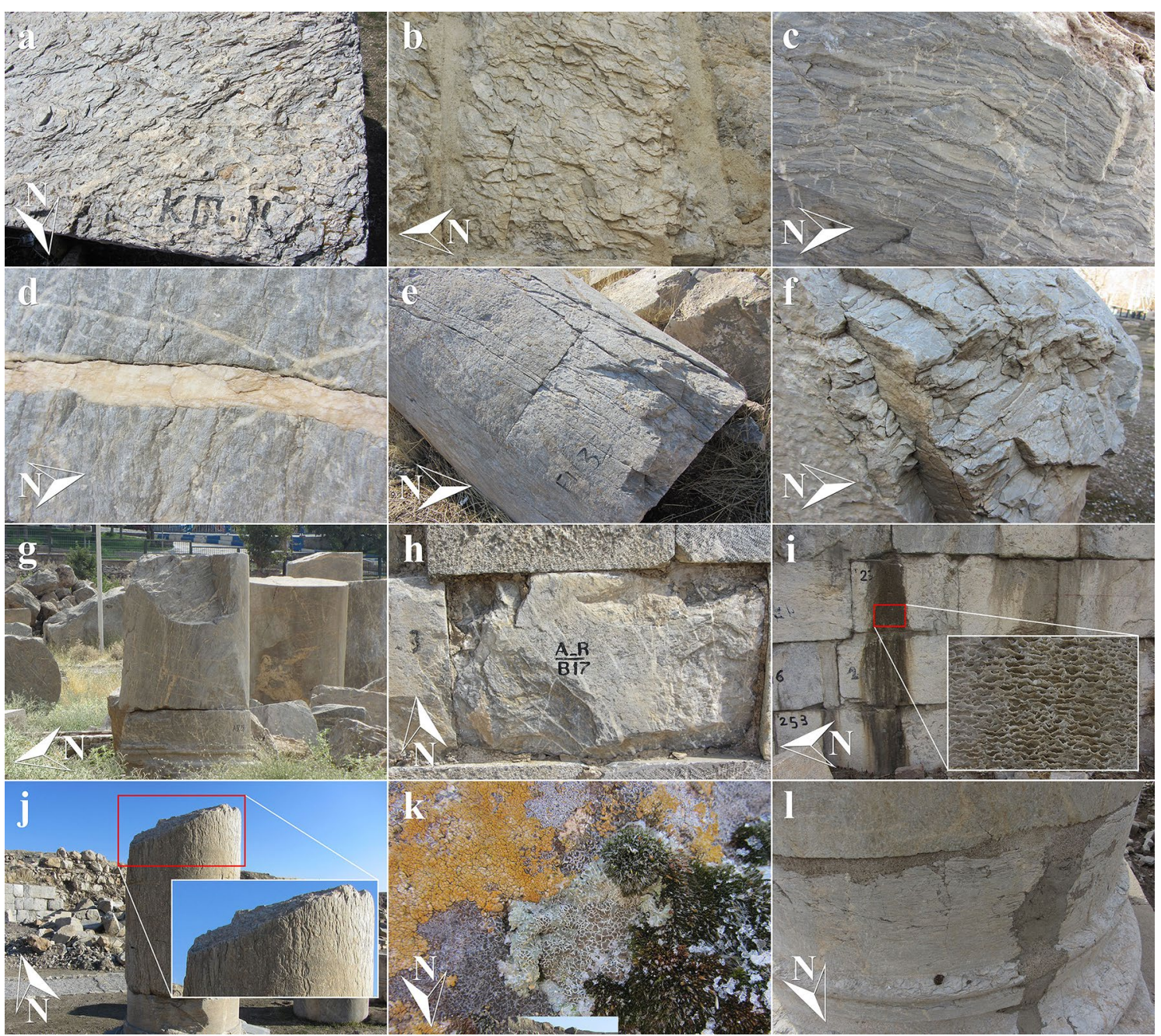

Fig. 6 Image of decay patterns of the stones used in the construction of Anahita Temple of Kangavar. a The scaling occurred in the south side of the monument which located in the area around the main building; $\mathbf{b}$ the scaling of the stone blocks forming the wall of the western side; $\mathbf{c}$ delamination of the layers of stone, the southern side of the monument; $\mathbf{d}$ the image showing the detachment of two layers with different colours from the columns located on the south side of the monument; $\mathbf{e}$ cracking occurred in a stone column, the eastern side of the site; $\mathbf{f}$ the detachment in a stone column on the western side of the monument; $\mathbf{g}$ the image of the bursting and the loss of stone in the south side of the monument; $\mathbf{h}$ bursting of the edges in the blocks of wall construction on the south side of the monument; $\mathbf{i}$ Alveolization and the formation of hard depositions on the surface of the wall of the western side of the monument; $\mathbf{j}$ the occurrence of the rillenkarren phenomenon in one of the columns located on the southern side of the site; $\mathbf{k}$ the growth of lichens on the stone surface located on the eastern side of the monument; I unsuitable intervention in the form of widespread use of cement to fill the loss parts of stones; the image shows the columns located on the western side of the monument

and empty veins of the stone as a restoration measure in recent decades (Fig. 6l); these cement layers are also detached from the stone surface as a deterioration event in some parts.

Study of the surface of stones in low magnification by stereomicroscope revealed two layers with different colours (limestone and soil) with detectable detachments (Fig. 7a). Figure $7 \mathrm{~b}$ illustrates the weathered surface of calcareous stone occurred in the form of small cracks. Furthermore, Fig. 7c shows large secondary calcite veins in the stone texture as one of the important features of the stones. In Fig. 7c, a small detachment at the boundary of the secondary calcite vein and the micritic texture is visible. Presence of microorganisms such as fungi and lichens is another type of deterioration that observable in cracks, veins and holes in the low magnification (Figs. 7d, e and f; see small colonies of fungi in Fig. 7d). Microorganism presence leads to chemical and physical deterioration of stone [67-70]. In some areas, the surface of the stone blocks has been lost due to the chemical 

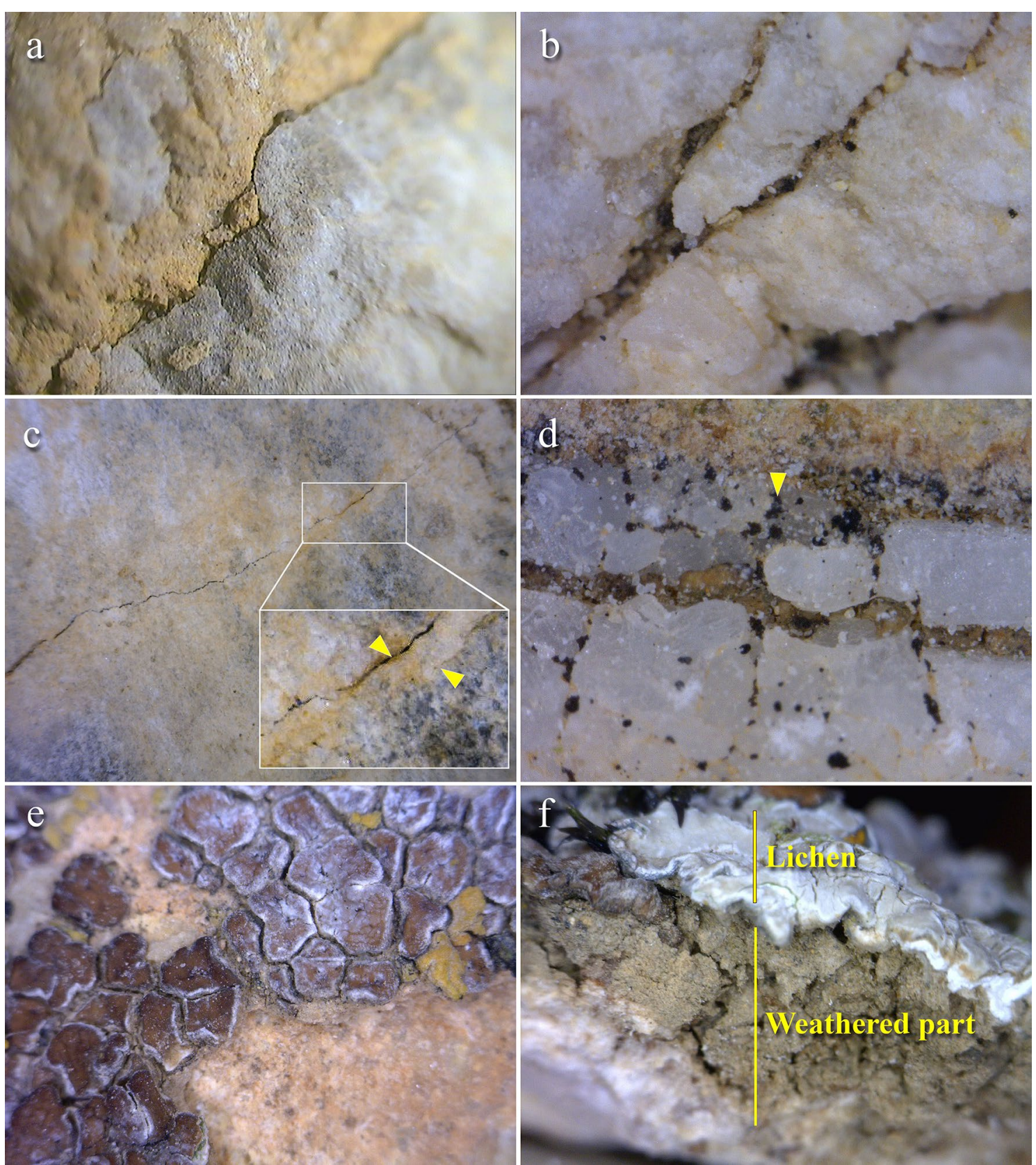

Fig. 7 Optical microscopy (OM) images of the surfaces of stones taken by stereomicroscope in low magnification (50 $x$ ). a The weathering surface of stone belonging to sample $\mathrm{K} 2$ that indicates the process of deterioration of the stone by separating clay vein and stone matrix; $\mathbf{b}$ the image of cracks in stone texture from sample K6; $\mathbf{c}$ the image of the detachment of secondary calcite from the texture of micrite, sample K1; $\mathbf{d}$ the image of fungi on the surface of stones, sample K7; e growth of lichen on the surface of stones and its influence on stone deterioration (sample K10); $\mathbf{f}$ the image of the stone deterioration by the growth of lichens in the weathered cross section of sample K10

and mechanical activities of lichens and transformed to powdery material. Figure $7 \mathrm{f}$ shows the deteriorated section of a stone block due to activity of lichens. This phenomenon is occurred in the form of the powdering of the stone surface which exposed to the lichens and resulted as by-products of lichen activities such as clay (muscovite) or calcium oxalate minerals (like weddellite $\left(\mathrm{Ca}\left(\mathrm{C}_{2} \mathrm{O}_{4}\right) 0.2\left(\mathrm{H}_{2} \mathrm{O}\right)\right)[71]$ in brown colour).

The X-ray diffractogram of thick crust on the surface of some stone blocks (sample K9) indicated gypsum as the major phase and calcite and quartz as the minor phases (Fig. 8). In fact, this crust is formed from gypsum and 


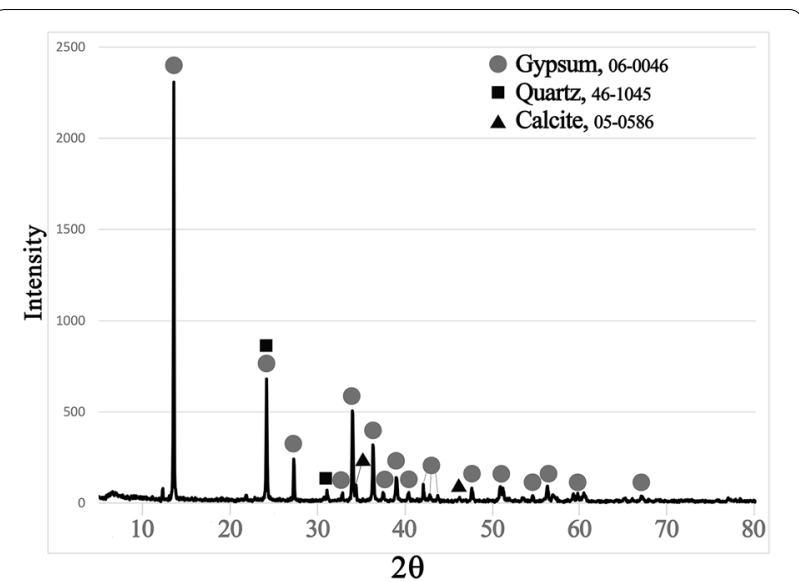

Fig. 8 The XRD pattern of the surface sediment on the stone (sample K9) from the eastern side of the Temple. The result indicates gypsum as major phase with calcite and quartz

its compsoitons is strongly different from the limestone itself. The gypsum crust may be related to the gypsum mortar used in the construction of the Anahita Temple, as had previously been observed in the construction of the inside core of the building [42]. The formation of the crust may be related to solubility of gypsum in presence of moisture/water followed by its recrystallization on the surface of the stone blocks.

SEM observations and semi-quantitative EDS analyses were performed on both unchanged section and surface of the stone. Figure 9 shows SE and BSE micrographs of the stone sections and deteriorated surface of the stone samples. SEM micrograph of the stone section in sample K2 (Fig. 9a) shows a significant compact texture of the limestone, while there are very few pores in its microscopic texture. Furthermore, the deterioration process of limestone is visible as micro-cracks and microdetachments. The micro-cracks and detachment can be observed in samples K1 and K8 (Fig. 9b, c). EDS analysis of stone matrix in sample $\mathrm{K} 2$ (analysis $\mathrm{A}$ ) shows that the main element is calcium, but low amounts of sodium, magnesium, aluminium, and silicon are also detected (Table 4). This analysis is well matched with the XRF analyses undertaken on the stone samples. BSE micrograph of sample K1 (Fig. 9b) shows a different phase from the Ca-rich matrix which is located in a cavity formed in the microstructure. EDS analysis of the phase (analysis B) revealed a $\mathrm{Si}$-rich phase containing some amount of aluminium and magnesium beside low amounts of calcium and sulphur. Analysis of stone matrix in sample K1 (analysis C, Fig. 9b) shows also a Ca-rich matrix beside silicon and about $4.3 \mathrm{wt} \%$ of magnesium. Sulphur is also measured in low amount in the EDS analysis of the matrix of sample K1 (Table 4, Fig. 9b).
Detachment of outer layer in the surface of the stone is occurred in the form of micro-cracks formed at the boundary of the grains in SE micrograph of sample K5 (Fig. 9d). One of the important events is detachment of grains; being shown in Fig. 9e, $\mathrm{f}$ (samples K8 and K1). In sample K6, there are evidences of dissolution at the grain boundaries in the surface of the stone (Fig. 9g). It can be a natural event due to the calcium carbonate solubility over time [51]. This type of deterioration is considerably less observed than the physical weathering events mentioned above (as micro-cracks and detachments). The EDS analysis of a phase in sample K6 (analysis D in Fig. 9g and Table 4) shows that the major element is calcium, while low amounts of silicon, sodium, aluminium, and potassium are detected too. Sulphur, phosphorus and chlorine have also been measured as minor elements. Matrix analysis of sample K6 (analysis E) also shows a Ca-rich texture beside other elements such as silicon, potassium, aluminium and sodium as possible representatives of clay minerals. The presence of lichen hyphae is another aspect observed in SEM micrographs of sample K10 (Fig. 9h, i). Some parts of stones were suffered by the biological attacks in the form of variable pores surrounding the lichen hyphae, with evidences of plate form clay minerals. Matrix analysis in sample K10 (analysis F in Table 4 and Fig. 9i) also presents calcium as the main element with 36.89 wt \% beside others representing chemical composition of clay as a minor phase. Phosphorus, sulphur, and chlorine have also been detected in low amount in analysis F. Presence of phosphorus may be an evidence of surface weathering exerted by biological agents [70]. Increasing the amount of some elements such as silica and aluminium in the analysis of surface occurs due to soil deposition on the surface of limestones. Analysis G in sample $\mathrm{K} 10$ of the lichens hyphae represents $\mathrm{Ca}$ with an almost high sulphur content as 9.87 wt \% (Table 4, Fig. 9i) which may indicate a presence of by-products of biological activity. The results of analysis $\mathrm{H}$ from sample $\mathrm{K} 10$ also shows $\mathrm{Ca}$ and $\mathrm{O}$ as main elements showing partially pure calcite phase (Table 4, Fig. 9i).

\section{Stone decay process in the Anahita Temple}

The results of analyses proved that the main reason of the deterioration of stones in the Anahita Temple is physical weathering. The greatest amount of deterioration turned out to be in form of detachments such as delamination, scaling, fragmentation and bursting. Scaling and other patterns make suitable conditions for water to penetrate inside the stone structure so that ultimately lead to disintegration and detachment after several thaw-freezing cycles [72]. Some deteriorations such as delamination of stones causes also good conditions for growth of biological colonisation. In microscopic scales, the deterioration 

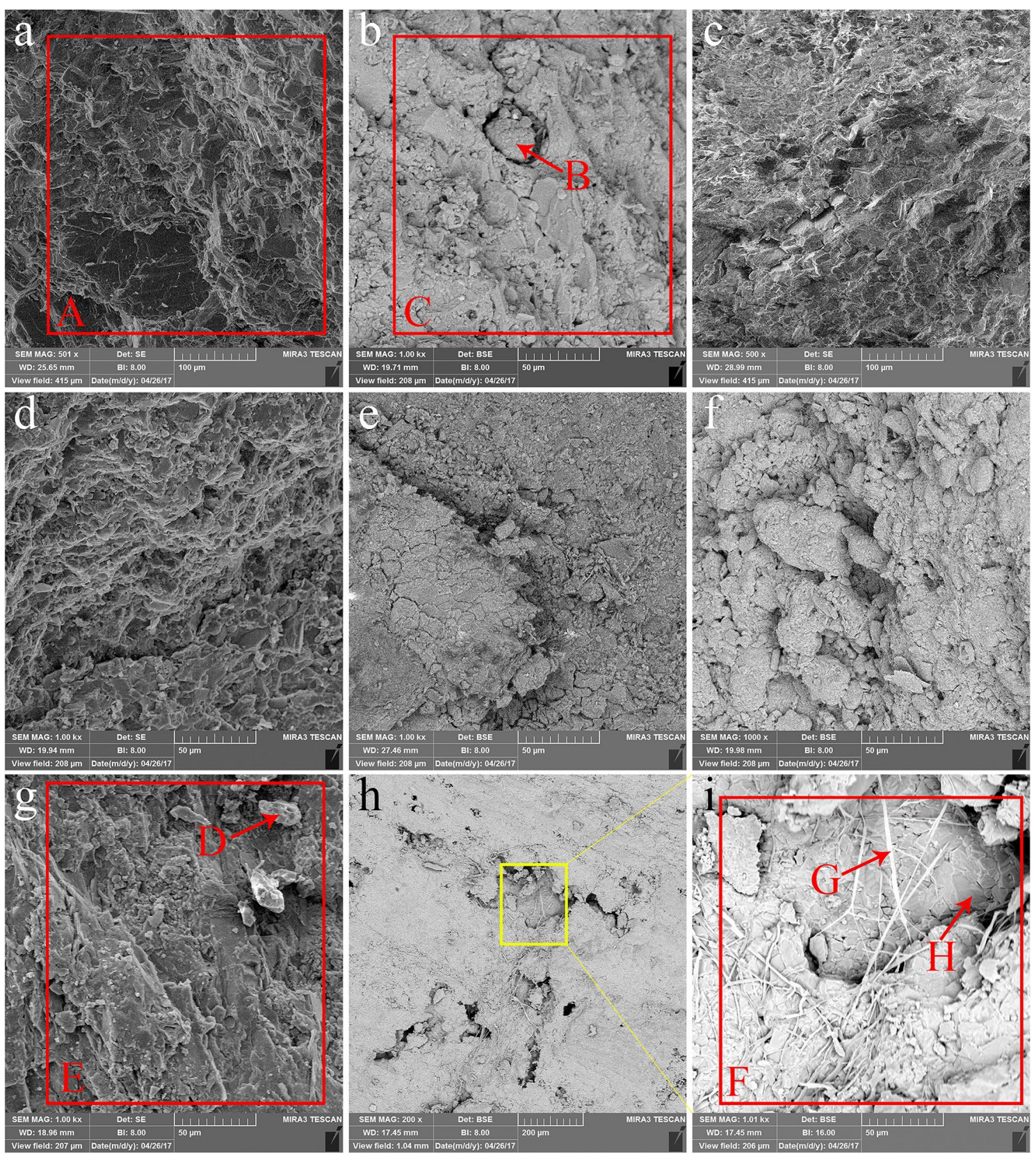

Fig. 9 SEM micrographs of the stone samples from the Anahita Temple including section and surface of stone samples. a The SE micrograph of the sample K2 that shows the compact structure and the intact texture of the stone; $\mathbf{b}$ the BSE micrograph of the sample K1 that indicate evidence of detached stone particles; the replacement of a phase is occurred in a cavity of the matrix texture; $\mathbf{c}$ the SE micrograph of the sample K8, in which a deterioration in the form of detachment of the stone's texture is visible. $\mathbf{d}$ the SE micrograph of sample K5 which represents the detachment of the layer; e grain detachment at stone surface in sample K8 in the form of BSE micrograph; $\mathbf{f}$ the BSE micrograph of sample K1 which shows the deterioration of stone as a grain detachment; $\mathbf{g}$ the image shows evidence of dissolution at the stone surface in sample K6 in the form of SEM micrograph; $\boldsymbol{h}$ the BSE micrograph of sample K10, the lichens hyphae in the stone texture; $\mathbf{i}$ the BSE micrograph of the area specified in yellow from sample K10, In the image, the lichens hyphae and degradation in the stone are visible. Results of EDS analyses are presented in Table 4

events occurred in form of detachment of the grains and layers as well as micro-cracks. On the other hand, there are little evidences of dissolution in the stones surfaces in macroscopic and microscopic scales. Decay resulted from presence of lichens also occurred due to their such activities as mechanical deterioration on the stones surfaces. In fact, hyphae penetration of the lichens into the stone pores leads to water conductivity with negative 
effects on narrow pores, as is observed in the stones of the Anahita Temple in freezing days. Thus, hyphae penetration of the lichen is responsible for the formation of channels and pores in the surface of the stones [73, 74]; which is also proved by the presence of phosphorus on the surface of stone blocks $[75,76]$. Other deterioration patterns are occured in forms of crust and rillenkarren. Rillenkarren phenomenon, as noted earlier, is mainly the result of the dissolution of soluble phases of stone, especially in the carbonate rocks [77-79]. It is noted in a previously published study on the stone weathering of the Anahita Temple of Kangavar [80] that this monument has seriously suffered from weathering due to long-term freezing-thawing and salt crystallization. Nevertheless, the results of present study indicate no significant evidence of the presnece of soluble salt effects and efflorescence and its deterioration in the Anahita Temple.

The Anahita Temple is exposed to the outdoor environment and is influenced by a variety of deteriorative factors, and the climate of the region can undoubtedly play an important role in the decay of the stones. According to the climatological data available from the meteorological station of Kangavar, the monument is located in an environment with almost warm and dry summers, while during cold seasons, the effects of rain precipitation and temperature fluctuations with high rate freezing, cause serious physical deterioration through different types of detachments. Figure 10 shows the average rainfall $(\mathrm{mm})$ and average maximum and minimum temperatures $\left({ }^{\circ} \mathrm{C}\right)$ recorded in the Kangavar region based on the data available from 1987 to 2014. The average rainfall in the region is variable, the highest of which being in March with $64.23 \mathrm{~mm}$, while the dry period of year covers a June to September interval (Fig. 10). According to the diagram, the highest average of maximum temperature (red line) is recoreded in July and the lowest average of minimum temperature (blue line) in February. It is visible that (a) the difference of maximum and minimun (average) temperatures is about $30^{\circ} \mathrm{C}$ (through whole of the year), and (b) temperature flactuations of the Kangavar region is comparatively considerable. In general, the Kangavar region is semi-dry and cold and rainfall is significant there especially in winter [48]. These variables are important factors influencing the physical deterioration of the stone blocks beside of their heterogeneous structure which increases the process and rate of weathering.

The presence of clay in the structure of limestone is always an influencing factor in physical weathering in particular, which may reduce the strength and other physical properties of limestone [81-83]. Presence of fine-grained clay minerals is a destructive factor in stone texture, as is clear in the analysis of limestone of the Anahita Temple [84-86]. Clay veins have a much lower strength than the main calcitic structure and can also absorb water, which leads to deterioration of clay-containing limestone [87-90]. Water can wash out and remove the unstable clay veins from the stone structure and also cause clay swelling that may be followed by penetration of water into voids and then freezing in cold season, leading to pressure generation round the surrounding stone structure. In fact, the cycles of thaw-freezing phenomenon in the stones of the Anahita Temple accelerate the physical weathering process produced by water penetration [72]. On the other hand, the structural variety of calcite with clay veins also causes detachment of layers due to different thermal expansion coefficients of different constituent phases of the stone structure. The clay minerals can't act as very destructive due to swelling, but they can cause deterioration due to osmotic swelling during the wet and dry cycles [91-94]. Thus, the capacity of osmotic swelling in the stones of the Anahita Temple should also be considered in intervention and restoration stages. Moreover, daily and seasonally changes of the moisture may lead to an increase or a decrease in the volume of clay, thereby introducing a mechanical stress to the structure of the stones, causing many micro- and macro-cracks and

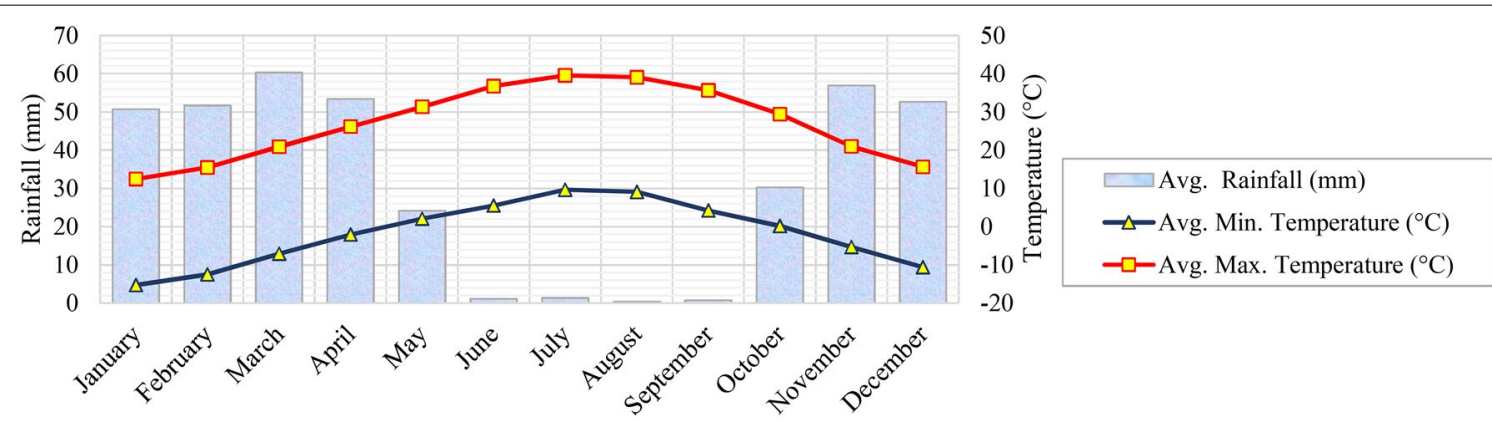

Fig. 10 Diagram of the monthly variation of meteorological data of Kangavar region from 1987 to 2014 showing average rainfall and average minimum and maximum temperature [48] 
several types of detachments in the stone structure [81, 93]. The osmotic swelling pressure is not too much, but its cycles may cause detachment forming in the boundaries of layers [81]. Hence, the clay veins in the structure of the stones are the most unstable parts of the structure, which ultimately results in the lamellae detachment of the limestone.

Based on the results, it can be derived that physical weathering has significant contribution to the deterioration of the limestone in the Anahita Temple. It originates from structural-chemical characteristics of stones (including non-homogeneous texture and various phases such as micritic matrix, secondary calcite, clay veins, etc.) and from temperature fluctuations and water penetrations in the Kangavar area [13, 91, 95-98]. The weathered veins (washed out) are visible in the form of scaling and delamination in the weathered stones. Based on the deterioration patterns, it can be stated that the decay process is in progress due to the shape and type of deteriorations. The occurred fissures, along with the absorption of water and its penetration into the cracks, as well as thaw-freezing phenomenon continue and contribute to the process of physical weathering.

No appropriate conservation measures have been performed in the Anahita Temple during and after excavation and study of the site. In some cases, some restorations and reconstruction operations took place in last decades, such as the use of sand-cement binder with large iron rebar and girder in some cases to re-join the broken stone blocks [28, 32, 33]. These restoration operations have led to a further decay in the stone blocks, among evidences of which being salt efflorescence due to using cement binder. Reasons such as increasing in the physico-chemical deterioration caused by water penetration, the introduction of soluble salts as well as physical deterioration in the form of shrinkage, show that sand-cement binder is an inappropriate material for restoration of limestone [99-102]. The presence of mass of soil under and behind the stone structure acts as a water storage, especially during the rainy seasons, and can make conditions even more proper for continuing deterioration in the stone blocks used in the construction of stone walls. These parts of the monument have underwent a long-term soaking and water absorption from behind of the stone wall during precipitation seasons (Fig. 11a). This is the reason of the high intensity of deterioration in the stone blocks used in the wall construction, especially in the eastern and western sides of the monument (Fig. 11b). These evidences prove that an integrated conservation plan, as a part of the site's management plan, is necessary so as to establish a strategy to make decisions on the conservation-restoration methods and materials, based on the results of study and characterization of the decay process occurred in the stone blocks of the Anahita Temple of Kangavar.

\section{Conclusion}

The stone blocks and pieces used in construction of the Anahita Temple of Kangavar have suffered from weathering in a highly intensive manner. Analytical studies carried out to identify chemical and microstructural characteristics of the stone and its decay patterns and processes. The stones used in the Temple are from heterogeneous low-porosity limestone/dolomitic limestone types, containing minor phases of silicates and clay minerals such as illite, albite and muscovite. An important feature of stones is the presence of various veins within the texture in different sizes. These veins consist of large secondary calcite (sparite) and very narrow clay veins mainly in bedding orientation. Also, the matrix of the stone includes homogeneous micrite texture with low porosity. Essentially, due to the heterogeneity of the limestone, the deteriorations are mostly occurred in detachment pattern types such as scaling,

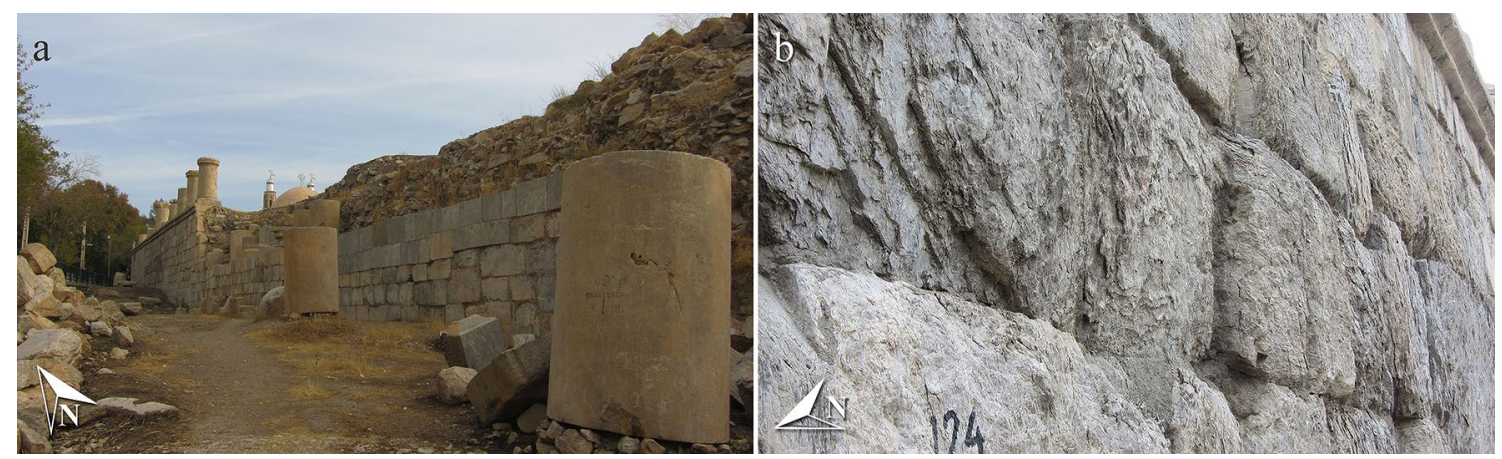

Fig. 11 a Images of the mass of soil behind the western wall of the monument; $\mathbf{b}$ close-up image of deteriorated blocks on the wall in the northwest area of the monument 
delamination, bursting and fragmentation. Other decay patterns include alveolization and biological colonisation such as lichens. There is some evidence of water dissolution and contamination on the surface of the stones, as the Anahita Temple is exposed to outdoor environ for roughly 2000 years. However, physical weathering has happened in greater content in comparison with other decay processes such as dissolution. Analytical works show that main reasons of delamination and fragmentation are the presence of secondary calcite veins and their detachment from the micritic texture in the boundary. Other reason is presence of clay veins in the microstructure of limestone that has led to splitting due to osmotic swelling, water penetration and its effect of freezing, as well as washing out and removal from the structure of the stone during exposure to water ( $\mathrm{RH} /$ rain). The climatic conditions of the region also provided conditions for thaw-freezing phenomenon to occur. Inadequate infrastructure in this monument beside other influential natural and human factors, either use of inappropriate restoration material or presence of the mass of soil behind the walls, contributed to deterioration of stone blocks in the Anahita Temple of Kangavar. The effect of temperature fluctuation on the stone decay by using laboratory simulations and aging as well as the appropriate restoration materials for stone can be considered for the future studies on the Anahita Temple. In addition, this deterioration process can be studied in limestone buildings and monuments in other regions to show the effect of stone structure on the physical weathering occurred in cultural heritage monumental constructions.

\section{Abbreviations}

OM: Optical microscopy; SEM-EDS: Scanning electron microscopy coupled with energy dispersive X-ray spectroscopy; XRD: X-ray diffraction; XRF: X-ray fluorescence.

\section{Acknowledgements \\ The authors are thankful to Dr. M. Yazdi, University of Isfahan, Dr. M. Moham- madi Achachlouei and Dr. P. Holakooei, Art University of Isfahan, P. Karami, University of Malayer, Dr. S. Alibaigi, Razi University of Kermanshah and F. Naz- ari, former director of the Cultural Heritage and Tourism Base of the Anahita Temple of Kangavar site for their helps during experiments, fieldworks and samplings in this study.}

\section{Authors' contributions}

VB studied the decay pattern of the stone of the Anahita Temple, Prepared samples for analysis by instrumentals and microscopy methods, contributed to the preparing draft of the paper and also read the text; $O O$ contributed to preparing the samples, contributed to the analytical works and interpretation of the analytical data as well as preparing the draft of the paper; AS contributed to the chemical analyses and petrographic studies, and read and corrected the final paper. All authors read and approved the final manuscript.

\section{Funding}

This research was funded by Art University of Isfahan.

\section{Availability of data and materials}

The datasets used and/or analysed during the current study are available from the corresponding author on reasonable request.

\section{Competing interests}

The authors declare that they have no competing interests.

Received: 24 January 2020 Accepted: 24 June 2020

Published online: 06 July 2020

\section{References}

1. Peacock D, Wright S, Mincham J. The archaeology of stone: a report for English Heritage, English Heritage Archaeological Monographs, English Heritage; 1998.

2. Shea JJ. Stone tools in the paleolithic and neolithic Near East, a guide. Cambridge: Cambridge University Press; 2013.

3. Selby M. Earth's changing surface: an introduction to geomorphology. Oxford: Clarendon Press; 1985.

4. Livingstone R. The application of petrology to the predication of stone durability. In: Proceedings of the 6th international congress on deterioration and conservation of stone, Torun: Nicholas Copernicus University Press; 1988. p. 432-45.

5. Loughman F. Chemical weathering of silicate minerals. New York: Elsevier; 1969.

6. Scrivano S, Gaggero L, Aguilar J. Micro-porosity and micro-petrographic features influences on decay: experimental data from four dimension stones. Constr Build Mater. 2018;173:342-9.

7. Vázquez P, Shushakova V, Gómez-Heras M. Influence of mineralogy on granite decay induced by temperature increase: experimental observations and stress simulation. Eng Geol. 2015;189:58-67.

8. Thornbush M, Viles $\mathrm{H}$. Simulation of the dissolution of weathered versus unweathered limestone in carbonic acid solutions of varying strength. Earth Surf Proc Land. 2007;32:841-52.

9. Kühnel R, Van der Gaast S, Brych J, Laan G, Kulnig H. The role of clay minerals in durability of rocks observations on basaltic rocks. Appl Clay Sci. 1994;9:225-37.

10. Gómez-Heras M, Smith B, Fort R. Surface temperature differences between minerals in crystalline rocks: implications for granular disaggregation of granites through thermal fatigue. Geomorphology. 2006;78:236-49.

11. Smith B. Rock temperature measurements from the northwest Sahara and their implications for rock weathering. Catena. 1977;4:41-63.

12. Weiss T, Siegesmund S, Kirchner D, Sippel J. Insolation weathering and hygric dilatation: two competitive factors in stone degradation. Environ Geol. 2004;46:402-13.

13. Doehne E, Price C. Stone conservation: an overview of current research. Los Angeles: Getty Conservation Institute; 2010.

14. Viles $\mathrm{H}$. Implications of future climate change for stone deterioration. Geol Soc Lond Spl Publ. 2002;205:407-18.

15. Massey S. The effects of ozone and NOx on the deterioration of calcareous stone. Sci Total Environ. 1999;227:109-21.

16. Charola A. Stone deterioration characterization for its conservation for conservation. Revista Geonomos. 2017;24:16-20.

17. Lisci M, Monte M, Pacini E. Lichens and higher plants on stone: a review. Int Biodeter Biodegr. 2003;51:1-17

18. Young M, Urquhart D. Algal growth on building sandstone: effects of chemical stone cleaning methods. Q J Eng Geol. 1998;31:315-24.

19. Zhang G, Gong C, Gu J, Katayama Y, Someya T, Gu J-D. Biochemical reactions and mechanisms involved in the biodeterioration of stone world cultural heritage under the tropical climate conditions. Int Biodeter Biodegr. 2019;143:104723.

20. Smith BJ, Gomez-Heras M, McCabe S. Understanding the decay of stone-built cultural heritage. Prog Phys Geog. 2008;32:439-61.

21. Rives V, Garcia-Talegon J. Decay and conservation of building stones on cultural heritage monuments. Mater Sci Forum. 2006;514-516:1689-94.

22. Shekofteh A, Molina E, Arizzi A, Cultrone G, Ahmadi H, Yazdi M. Characterization and damage assessment of stones used in the Pasargadae World Heritage Site, Achaemenian period. Int J Archit Herit. 2019;13:521-36. 
23. Ortega-Morales O, Montero-Muñoz JL, Baptista Neto JA, Beech IB, Sunner J, Gaylarde C. Deterioration and microbial colonization of cultural heritage stone buildings in polluted and unpolluted tropical and subtropical climates: a meta-analysis. Int Biodeter Biodegr. 2019;143:104734

24. Saba M, Quiñones-Bolaños EE, Martínez Batista HF. Impact of environmental factors on the deterioration of the Wall of Cartagena de Indias. J Cult Herit. 2019;39:305-13.

25. Saba M, Quiñones-Bolaños EE, Barbosa López AL. A review of the mathematical models used for simulation of calcareous stone deterioration in historical buildings. Atmos Environ. 2018;180:156-66.

26. Theodoridou M, Török Á. In situ investigation of stone heritage sites for conservation purposes: a case study of the Székesfehérvár Ruin Garden in Hungary. Progress Earth Planet Sci. 2019. https://doi.org/10.1186/ s40645-019-0268-z.

27. Alibaigi S. Additional remark about the function of the so-called Anahita Temple monumental in Kangavar, Kermanshah: a clue to solve an old problem. Dabir. 2017:4:8-14.

28. Kambakhshfard S. Kangavar Anahita Temple, Archaeological excavations and studies and architectural reconstruction and renovation of Anahita Temple and Taq-e Gara, Vol. 1. Tehran: ICHO Publications; 1995 (In Persian).

29. Heidari A. Spatial study of architecture Anahita Temple of Kangavar. Stud Iran Islamic City. 2012;7:73-86 (In Persian).

30. Kambakhshfard S. Kangavar. In: Kiani MY, editor. Iranian Cities. Tehran: Jahad-e Daneshgahi Press; 1989. p. 107-50 (In Persian).

31. Tilia AB. A study on the methods of working and restoring stone and on the parts left unfinished in Achaemenian architecture and sculpture. East West. 1968;18(1-2):67-95.

32. Kambakhshfard S. Kangavar Anahita Temple, Archaeological excavations and studies and architectural reconstruction and renovation of Anahita Temple and Taq-e Gara, Vol. 2. Tehran: ICHO Publications; 1995 (In Persian).

33. Mehryar M, Kabiri A. Continuation of Excavations in Kangavar Anahita Temple. PAJOOHASHGAH: ICHTO; 2004 (In Persian).

34. Azarnoush M. Excavayions at Kangavar. Archäologische Mittilungen aus Iran. 1981;14:69-94.

35. Azarnoush M. New evidence on the chronology of the Anahita Temple. Iranica Antiqua. 2009;XLIV:393-402.

36. Calmeyer P. Die Landschaft Kambadēnē. In: Kleiss W, Kalmayer P. Bisutun: Ausgrabungen und froschngen inden jarden 1963-1967. Teheraner Forschungen VII. Berlin: Gebr. Mann Verlag; 1996. p. 13-14

37. Kleiss W. Kangavar. In: Yarshater E, editor. Encyclopedia Iranica, Vol. XV. California: Mazda Publisher; 2010. p. 496-97.

38. SchoffW. Parthian stations, by Isidore of Charax, An account of the overland Trade route between the Levant and India in the first century B.C., The Greek text with a Translation and Commentary. Transcribed from The Original London Edition; 1914.

39. Aires Barros K, Christensen C. Modes and mechanisms of rock weathering. In: Galán Huertos E, Zezza F, editors. Protection and conservation of the cultural heritage of the Mediterranean cities: proceedings of the 5th International Symposium on the Conservation of Monuments in the Mediterranean Basin. Sevilla, Spain: Balkema Publishers; 2002. p. 3-9.

40. Siegesmund S, Weiss T, Vollbrecht A. Natural stone, weathering phenomena, conservation strategies and case studies: introduction. Geol Soc Lond Spl Publ. 2002;205:1-7.

41. Lal Gauri K, Bandyopadhyay J. Carbonate stone: chemical behavior, durability, and conservation. 1st ed. New York: Wiley; 1999.

42. Shekofteh A, Oudbashi O, Cultrone G, Ansari M. Geochemical and petrographic identification of stone quarries used for the construction of the Anahita Temple of Kangavar (West Iran). Herit Sci. 2020;8:14.

43. Flügel E. Microfacies of carbonate rocks - analysis, interpretation and application. Berlin, Heidelberg: Springer; 2004.

44. Bruton G. Vapour glycolation. Am Mineral. 1955;40:124-6.

45. González García S, Sánchez Camazano M. Differentiation of kaolinite from chlorite by treatment with dimethylsulphoxide. Clay Miner. 1968;7:447-50.

46. Moore D, Reynolds R. X-ray diffraction and the identification and analysis of clay minerals, Vol. 378. Oxford: Oxford University Press; 1989.
47. UNE-EN 1936. Natural stone test methods. Determination of real density and apparent density and of total and open porosity. Madrid: AENOR; 2007.

48. http://www.irimo.ir/far/index.php. Accessed 30 June 2017.

49. Chilingar GV. Classification of limestones and dolomites on basis of Ca/Mg ratio. J Sediment Res. 1957;27(2):187-9.

50. Frolova EK. On classification of carbonate rocks of limestone-dolomite-magnesite series: novosti Neft. Tekhniki (Geology). 1959;3:34-5.

51. Geyssant J. Geology of calcium carbonate, from mineral to rock-the deposits. In: Tegethoff FW, editor. Calcium carbonate, from the cretaceous period into the 21 th Century. In collaboration with Rohleder J, Kroker E. Basel: Springer. 2001. p. 1-52.

52. Pettijohn F, Potter P, Siever R. Sand and sandstone. New York: Springer-Verlag; 1987.

53. Das B, AL-Mikhalafi A, Kaur P. Geochemistry of Mansar Lake sediments, Jammu, India: Implication for source-area weathering, provenance, and tectonic setting. J Asian Earth Sci. 2006;26:649-68.

54. Mackenzie W, Guilford C. Atlas of rock-forming minerals in thin section. Abingdon: Routledge; 2014.

55. Winkler E. Stone: properties, durability in man's environment. Berlin: Springer-Verlag; 1997.

56. Klein C, Hurlbut CS Jr. Manual of Mineralogy, Revised 21st edn (after Dana JD). Toronto: Wiley; 1999.

57. Cardarelli F. Material's handbook: a concise desktop reference. London: Springer Science \& Business Media; 2008.

58. Foster $M$. The relation between composition and swelling in clays. Reston: U.S. Geological Survey; 1955. p. 54-91.

59. Gaudette H, Eades J, Grim R. The nature of Illite. Clay Clay Miner. 1964;13:33-48.

60. ICOMOS-ISCS. Illustrated glossary on stone deterioration patterns. ICOMOS-ISCS; 2008.

61. Siedel H, Siegesmund S, Sterflinger K. Characterization of stone deterioration on buildings. In: Siegesmund S, Snethlage R, editors. Stone in architecture: properties, durability. Berlin: Springer; 2011. p. 347-410.

62. Janvier-Badosa S, Beck K, Brunetaud X, Al-Mukhtar M. The occurrence of gypsum in the scaling of stones at the Castle of Chambord (France). Environ Earth Sci. 2014;71:4751-9.

63. Berberian $M$, Yeats R. Contribution of archaeological data to studies of earthquake history in the Iranian Plateau. J Struct Geol. 2001;23:563-84.

64. Glew JR, Ford DC. A simulation study of the development of rillenkarren. Earth Surf Proc Land. 1980;5:25-36.

65. Lowe D, Waltham T. A dictionary of karst and caves: a brief guide to the terminology and concepts of cave and karst science. London: BCRA; 1995.

66. Mcllroy de la Rosa JP, Porcel MC, Warke PA. Mapping stone surface temperature fluctuations: Implications for lichen distribution and biomodification on historic stone surfaces. J Cult Herit. 2013;14:346-53.

67. De La Tore M, Gomez Alarcon G, Melgarejo P, Saiz Jiminez C. Fungi in weathered sandstone from Salamanca Cathedra. Sci Total Environ. 1991;107:159-68.

68. Saiz-Jimenez C. Biodeterioration of stone in historic buildings and monuments. In: Llewellyn GC, Dashek WV, O'Rear CE, editors. Mycotoxins, wood decay, plant stress, biocorrosion, and general biodeterioration. Biodeterioration Research, Vol. 4. Boston: Springer; 1994. p. 587-604.

69. Scheerer S, Ortega-Morales O, Gaylarde C. Microbial deterioration of stone monuments-an updated overview. In: Laskin AL, Saraslani S, Gadd G, editors. Advances in microbiology, Vol 66; 2009, p. 97-139.

70. Lyalikova NN, Petushkova YP. Role of microorganisms in the weathering of minerals in building stone of historical buildings. Geomicrobiol J. 1991;9:91-101.

71. Chan Hee L, Myeong Seong L, Jiyoung K. Weathering and degradation assessment of rock properties at the west stone Pagoda, Gameunsaji Temple Site, Korea. Conserv Restor Cult Herit. 2012;1:29-37.

72. Chen T, Yaung M, Mori N. Effect of water saturation on deterioration of welded tuff due to freeze-thaw action. Cold Reg Sci Technol. 2004;38:127-36.

73. Concha-Lozano N, Gaudon P, Pages J, De Billerbeck G, Lafon D, Eterradossi $O$. Protective effect of endolithic fungal hyphae on oolitic limestone buildings. J Cult Herit. 2012;13:120-7. 
74. Ascaso C, Wierzchos J, Souza-Egipsy V, De Los Rí A, Rodrigues JD. In situ evaluation of the biodeteriorating action of microorganisms and the effects of biocides on carbonate rock of the Jeronimos Monastery (Lisbon). Int Biodeter Biodegr. 2002;49:1-12.

75. Banfield J, Barker W, Welch S, Taunton A. Biological impact on mineral dissolution: application of the lichen model to understanding mineral weathering in the rhizosphere. Proc Natl Acad Sci. 1999;96:3404-11.

76. Wierzchos J, Carmen A. Mineralogical transformation of bioweathered granitic biotite, studied by HRTEM: evidence for a new pathway in lichen activity. Clay Clay Miner. 1998;46:446-52.

77. Williams P. World heritage caves and karst: a thematic study. Gland: IUCN: International Union for Conservation of Nature; 2008.

78. Eren M, Hatipoglu-Bagci Z. Karst surface features of the hard laminated crust (Caliche Hardpan) in the Mersin area, Southern Turkey. Acta Carsologica. 2010;39:93-102.

79. Mottershead DN. A study of solutional flutes (Rillenkarren) at Lluc, Mallorca. Zeitschrift für Geomorphologie, Supplementband. 1996;103:215-41.

80. Heidari M, Torabi-Kaveh M, Mohseni H. Assessment of the effects of freeze-thaw and salt crystallization ageing tests on Anahita Temple stone, Kangavar, west of Iran. Geotech Geol Eng. 2016;35:121-36.

81. Rodrigues JD. Swelling behavior of stones and its interest in conservation. An appraisal. Materiales de Constructión. 2001;51:183-95.

82. Rodríguez-Navarro C, Hansen E, Sebastian E, Ginell W. The role of clays in the decay of ancient Egyptian limestone sculptures. J Am Inst Conserv. 1997;36:151-63.

83. Cherblanc F, Berthonneau J, Bromblet P, Huon V. Influence of water content on the mechanical behavior of limesonte: role of clay minerals content. Rock Mech Rock Eng. 2016;49:2033-42.

84. Caner E, Seeley N. The clay minerals and the decay of limestone. In: International symposium on deterioration and protection of stone monuments. Paris: UNESCO/RILEM; 1978.

85. Meunier A. Why are clay minerals small? Clay Miner. 2006:41:551-66.

86. Sebastian E, Cultrone G, Benavente D, Linares Fernandez L, Elert K, Rodriguez-Navarro C. Swelling damage in clay-rich sandstones used in the church of San Mateo in Tarifa (Spain). J Cult Herit. 2008;9:66-76.

87. Petry T, Little D. Review of stabilization of clays and expansive soils in pavements and lightly loaded structures-history, practice, and future. J Mater Civil Eng. 2002;14:447-60.

88. Benavente D, Cultrone G, Gomez-Heras M. The combined influence of mineralogical, hygric and thermal properties on the durability of porous building stones. Eur J Mineral. 2008;20(4):673-85.

89. Berthonneau J, Grauby O, Bromblet P, Vallet JM, Dessandier D, Baronnet A. Role of swelling clay minerals in the spalling decay mechanism of the « pierre du midi » limestone (South-East of France). In: 12th international congress on the deterioration and conservation of stone. 22-26 October 2012 New York, États-Unis, 2012.

90. Wüst R, McLane J. Rock deterioration in the Royal Tomb of Seti I, Valley of the Kings, Luxor, Egypt. Eng Geol. 2000;58:163-90.

91. Jiménez-González I, Rodríguez-Navarro C, Scherer G. Role of clay minerals in the physicomechanical deterioration of sandstone. J Geophys Res Earth. 2008;113:1-17.

92. Madsen F, Müller-Vonmoos M. The swelling behavior of clays. Appl Clay Sci. 1989;4:143-56.

93. Veniale F, Setti M, Rodríguez-Navarro C, Lodola S. Procesos de alteración asociados al contenido de minerales arcillosos en materiales pe'treos. Materiales de Construccion. 2001;51:163-82.

94. Rodriguez-Navarro C, Sebastián E, Doehne E, Ginell W. The role of sepiolite-palygorskite in the decay of ancient Egyptian limestone sculptures. Clay Clay Miner. 1999:46:414-22.

95. Charola A, Ware R. Acid deposition and the deterioration of stone: a brief review of a broad topic. Geol Soc Lond Spl Publ. 2002;205:393-406.

96. El-Gohary M. Effective roles of some deterioration agents affecting Edfu royal Birth House "Mammisi". Int J Conserv Sci. 2015;6:349-68.

97. Trudgill ST, Viles HA. Field and laboratory approaches to limestone weathering. Q J Eng Geol Hydroge. 1998;31:333-41.

98. Eslami J, Walbert C, Beaucour A-L, Bourges A, Noumowe A. Influence of physical and mechanical properties on the durability of limestone subjected to freeze-thaw cycles. Constr Build Mater. 2018;162:420-9.

99. Griswold J, Uricheck S. Loss compensation methods for stone. J Am Inst Conserv. 1998;37:89-110.

100. Torney C. "Plastic" repair of natural stone in Scotland: perceptions and practice. Struct Surv. 2012;30(4):297-311.

101. André M-F, Voldoire O, Vautier F, Roussel E, Phalip B, Morel D. Impact of cement repointing on rates of sandstone decay in medieval churches of the French Massif Central. In: Cassar J, Winter MG, Marker BR, Walton NRG, Entwisle DC, Bromhead EN, Smith JWN, editors. Stone in historic buildings: characterization and performance, Vol 391. Geological Society, London, Special Publications, 2014. p. 157-74.

102. Corinaldesi V. Environmentally-friendly bedding mortars for repair of historical buildings. Constr Build Mater. 2012;35:778-84.

\section{Publisher's Note}

Springer Nature remains neutral with regard to jurisdictional claims in published maps and institutional affiliations.

\section{Submit your manuscript to a SpringerOpen ${ }^{\circ}$ journal and benefit from:}

- Convenient online submission

- Rigorous peer review

- Open access: articles freely available online

- High visibility within the field

Retaining the copyright to your article

Submit your next manuscript at $\boldsymbol{\nabla}$ springeropen.com 